\title{
Remittances and labor supply in post-conflict Tajikistan
}

\author{
Patricia Justino ${ }^{1}$ and Olga N Shemyakina ${ }^{2^{*}}$
}

\author{
* Correspondence: olga. \\ shemyakina@econ.gatech.edu \\ ${ }^{2}$ School of Economics, Georgia \\ Institute of Technology, Atlanta, GA \\ 30332-0615, USA \\ Full list of author information is \\ available at the end of the article
}

\begin{abstract}
We analyze the impact of remittances on the labor supply of men and women in post-conflict Tajikistan. Individuals from remittance-receiving households are less likely to participate in the labor market and supply fewer hours when they do. The results are robust to different measures of remittances and migration. When we differentiate between regions by their exposure to the 1992-1998 armed conflict, we observe that the negative effect of remittances on the labor supply of women is primarily driven by women from the regions more exposed to fighting and destruction during the war. Remittances have a similar negative effect on the supply of labor hours worked across all regions, both for men and women. Further, in the households that do not have migrants, remittances have no effect on the labor supply by males, suggesting that migration and not remittances is the primary factor explaining male labor force participation.
\end{abstract}

JEL codes: J22, Time Allocation and Labor Supply; F22, International Migration; F24, Remittances; 012, Microeconomics Analyses of Household Behavior

Keywords: Migration, Remittances, Labor markets, Tajikistan, Gender, Armed conflict

\section{Introduction and motivation}

Labor migration has become an important component of household coping strategies in countries affected by armed conflict, either as an ex-ante reaction to the threat of conflict, or an ex-post response to unstable economic and political conditions (Engel and Ibanez 2007, Czaikas and Kis-Katos 2009). The significance of labor migration in conflictaffected countries is reflected in the large increase in remittances to migrant and refugee exporting countries that have experienced recent political crises (Goldring 2002).

In this paper, we investigate the impact of remittances on individual labor supply in post-conflict Tajikistan, a country that experienced some of the most significant migration flows in its recent history ${ }^{1}$, but remains largely under-researched as a case study. Based on the official data for Tajikistan (Table 1), around eight percent of the population left the country between 1991 and 2005. About 83.8 percent of them left during between 1991 and 1998, which overlaps with the 1992-1998 armed conflict in Tajikistan. By 2005, almost every family in Tajikistan had sent at least one family member abroad as a migrant worker (IMF 2005).

In line with the literature on effect of armed conflict on households and individuals, in our analysis we differentiate between the regions by their exposure to the 1992-1998 armed conflict in Tajikistan. We analyze the differences in the impact of remittances on the individual decision to participate in the labor market and on the number of

(c) 2012 Shemyakina and Justino; licensee Springer. This is an Open Access article distributed under the terms of the Creative Commons Attribution License (http://creativecommons.org/licenses/by/2.0), which permits unrestricted use, distribution, and reproduction in any medium, provided the original work is properly cited. 
Table 1 Migration flows, Tajikistan 1991-2005 (thousand persons)

\begin{tabular}{cclllll}
\hline Year & Arrived & Departed & $\begin{array}{l}\text { Migration inflows } \\
(+) / \text { outflows }(-)\end{array}$ & $\begin{array}{l}\text { Including: arrived } \\
\text { from abroad }\end{array}$ & $\begin{array}{l}\text { Including: left } \\
\text { for abroad }\end{array}$ & $\begin{array}{l}\text { International } \\
\text { migration inflows } \\
(+) / \text { outflows }(-)\end{array}$ \\
\hline 1991 & 74.9 & 101.3 & -26.4 & 20.0 & 48.6 & -28.6 \\
\hline 1992 & 51.3 & 146.0 & -94.7 & 11.3 & 104.7 & -93.4 \\
\hline 1993 & 71.4 & 146.1 & -74.7 & 12.0 & 86.3 & -74.3 \\
\hline 1994 & 43.3 & 88.8 & -45.5 & 6.6 & 55.1 & -48.5 \\
\hline 1995 & 37.1 & 74.9 & -37.8 & 5.5 & 45.3 & -39.8 \\
\hline 1996 & 26.1 & 53.7 & -27.6 & 3.7 & 34.1 & -30.4 \\
\hline 1997 & 20.2 & 37.0 & -16.8 & 3.3 & 21.1 & -17.8 \\
\hline 1998 & 16.9 & 32.3 & -15.4 & 2.7 & 17.6 & -14.9 \\
\hline 1999 & 14.7 & 28.8 & -14.1 & 1.8 & 14.7 & -12.9 \\
\hline 2000 & 14.5 & 28.2 & -13.7 & 1.7 & 14.6 & -12.9 \\
\hline 2001 & 16.7 & 29.1 & -12.4 & 1.7 & 12.9 & -11.2 \\
\hline 2002 & 17.7 & 30.2 & -12.5 & 1.4 & 12.0 & -10.6 \\
\hline 2003 & 16.9 & 27.9 & -11.0 & 1.4 & 10.2 & -8.8 \\
\hline 2004 & 15.2 & 24.6 & -9.4 & 1.1 & 7.9 & -6.8 \\
\hline 2005 & 18.0 & 27.3 & -9.3 & 1.1 & 7.3 & -6.2 \\
\hline
\end{tabular}

Source: State Statistical Committee (2006).

work hours supplied by men and women living in more conflict affected areas, in comparison to individuals in regions less exposed to the war. To study this question, we use individual and household-level data from the 2003 Tajik Living Standards Measurement Study (henceforth, 2003 TLSS) survey. We combine these data with information on violent events during the 1992-1998 civil war in Tajikistan based on two Russian-language newspapers published in Tajikistan, reports by non-governmental organizations, mentions of the conflict in books (e.g. Bliss 2010; Gomart 2003) and daily accounts of the 1992 and 1993 events that rely mostly on government records (Nazriev and Sattorov 2005, 2006).

The development literature has long recognized the importance of migration (and resulting remittances) as a mechanism used by households in the times of peace to secure income and improve welfare. There is a large literature that examines the impact of remittances on a number of household-level economic outcomes such as consumption decisions (Adams 2005), production (Damon 2010), schooling (Acosta 2006; Amuedo-Dorantes and Pozo 2010) and labor supply (Acosta 2006; Amuedo-Dorantes and Pozo 2006; Damon 2007; Hanson 2007). Studies on the relationship between remittances and labor supply find that an increase in remittances has a negative effect on labor hours supplied and labor force participation by men and women of working age and that the effect is often greater for women. Authors suggest that remittances are a source of non-labor income. An increase in non-labor income is often associated with a decrease in the opportunity cost of leisure and the relaxation of credit constraints. These effects in turn allow for a greater tolerance of risk and increased participation in self-employment. Some of the studies focus on countries affected by conflict in the past (e.g. El-Salvador (Acosta 2006; Damon 2007), Nicaragua (Funkhouser 1992)), but they do not take directly into account the effect of conflict on the outcome of interest. This approach may lead to potentially significant omitted variable bias since violent conflict may affect the very structure of labor markets, as well as fundamental individual incentives, tastes and preferences, leading households to make decisions in a way that differs 
from what they would have done in peaceful settings (see reviews by Blattman and Miguel 2010; Justino 2009, 2012).

The contribution of this paper is threefold. First, we examine the transfers from private and institutional donors to households by their exposure to the 1992-1998 conflict in Tajikistan. Second, we attempt to advance current understanding of the role of remittances in post-conflict settings by looking at the differentiated ways in which individual labor supply (of men and women aged 16-65) responds to remittance flows, differentiating between communities by their exposure to the 1992-1998 armed conflict. Third, we contribute to the emerging literature on the economic impact of armed conflict by analyzing important labor market effects for civilians (e.g. Fernández et al. 2011; Menon and Rodgers 2011).

Similar to previous literature, we find that the amount of remittances received by a given household has an overall negative impact on the labor force participation and hours supplied by men and women. In the full sample, the negative effect of remittances is found to be stronger for men than for women. Such a result is intriguing as previous research on the effects of remittances on labor supply has shown that female labor supply is typically more responsive to changes in remittances (Amuedo-Dorantes and Pozo 2006; Funkhouser 1992; Hanson 2007). The differences between our results and those of the existing literature can be explained by the differences in the samples used, as well as by the differences in the institutional settings. Notably, Tajikistan is a country that is transitioning from the Soviet planned economy into an independent one. The country also experienced a severe civil war that resulted in casualties amounting to between 50,000 and 100,000 people, large population displacement and destruction of industrial and agricultural assets (Bliss 2010; Falkingham 2000). When we differentiate by community's exposure to the conflict, we find that the labor force participation of women in the communities that suffered from greater physical damage and loss of life during the civil war is negatively associated with the receipt of remittances, suggesting that remittances were used as a coping strategy by the households in these regions.

The next section discusses the main hypotheses tested in the paper and the conceptual framework. Section 3 discusses our empirical specification and the main independent variables of interest. Section 4 presents data and preliminary observations. Section 5 describes the main empirical results. The last section concludes the paper.

\section{Conceptual framework and econometric specification}

\section{Conceptual framework}

Previous empirical findings show that inflows of remittances are associated with reductions in the labor force participation of both men and women. In the neoclassical model of labor-leisure choice (Killingsworth 1983), remittances can be interpreted as non-labor income. Theoretically, an increase in non-labor income should increase household purchasing power and reservation wages, therefore reducing the need of employment and the number of hours supplied by remittance-receiving individuals (Killingsworth 1983). However, households may initially have to finance the outmigration of the household members and some household members that stayed at home may have to enter the labor force to repay for the migration costs. They may also be forced into the labor force if their labor and the labor inputs of migrants are substitutes as suggested by Amuedo-Dorantes and Pozo (2006). 
The theoretical implications above have been tested empirically only in the times of peace. If work migration is related to armed conflict, then analyses of the effects of remittances in conflict-affected countries that do not account for the effect of conflict will suffer from potential omitted variable bias. The effect of remittances on household economic decisions, including migration and labor supply, in conflict-affected areas is unclear from a theoretical point of view. First, exposure to conflict increases the likelihood of death, injury and asset loss by household members. If remittances sent by a migrant household member are a substitute for the loss of household adult workers, then it is possible that the receipt of remittances will not yield any effects on the labor supply of household members that stayed behind. Alternatively, remittances may be accompanied by increases in labor participation of household members that stayed behind if the remittance funds cannot entirely substitute for the loss of income. Recent studies also show that conflict may affect risk perceptions (Voors et al. 2012) and shorten people's planning horizons (Bozzoli and Muller 2010). These changes in preferences may provide incentives for people to remain employed even if remittances could substitute for wage employment.

We expect to observe significant differences between male and female responses to remittances in conflict-affected areas. Armed conflict is associated with significant changes in gender relations as women that would typically have stayed at home adopt different roles to cope with the absence of males or with changes in the structure of society (see Annan et al. 2011 for a discussion). One of such new roles is the breadwinner role, where women who previously stayed at home join the labor force to provide for their families. High levels of female-headship are often observed in communities affected by violent conflict (Annan et al. 2011; Brück and Schindler 2009). In the context of Tajikistan, war forced many widows to tend for themselves and their children. Many men, especially, in the eastern Khatlon and Raions of Republican Subordination could not leave their communities to find work in Tajikistan due to persecution, and women had to take on jobs to provide for their families (Human Rights Watch 1993, 1995; Tadjbakhsh 1996). These new roles may contribute to changes in women's preferences and attitudes whereby women will be reluctant to leave the labor market for the fear of losing their newly found autonomy even in response to flows of non-wage income to the household (such as remittances).

\section{Econometric framework}

We start the analysis of labor market outcomes by estimating key factors that may affect an individual's decision to actively participate in the labor market. We use individual employment status in the 14 days prior to the survey as a proxy for workforce participation ${ }^{2}$. The empirical model is presented in Equation 1.

$$
E_{i j n k}=\alpha_{k}+R_{j} \eta+Z_{i} \gamma+C_{n} \beta+u_{i j n k}
$$

where $E_{i n j k}$ is a binary variable indicating whether an individual $i$ living in household $j$, primary sampling unit $n$ and district $k$ was employed in the 14 days preceding the survey ${ }^{3} . \alpha_{k}$ are district level fixed effects, $R_{j}$ is the amount of remittances received by household $j$ in the 12 months prior to the survey.

$Z_{i}$ is a vector of individual, such as age, gender of and years of education completed by an individual, and household characteristics, such as dependency ratio (number of dependents to adults ages 16-65), female headship, household size and non-wage 
income ${ }^{4}$. Finally, $C_{n}$ is the vector of community characteristics that vary within a district such as rural location.

To control for unobserved correlations of the observations within communities, equation (1) is estimated using district-level fixed effects. This specification allows us to include in the regressions characteristics that vary within districts, such as rural/urban location. All regressions are estimated with robust standard errors clustered at the district-level to control for the effect of unobserved heterogeneity. The fixed-effects model eliminates all observed and unobserved community characteristics that are constant across individuals from the same community. This removes any potential bias in the estimation of labor supply caused by individual-invariant community characteristics, assuming that these community effects do not interact with household and individual characteristics. Since it is possible that some unobservable community characteristics, such as availability of jobs, are correlated with remittances, the fixed effects specification helps us to control for this correlation. We assume that there are no omitted time-varying and region specific effects correlated with the remittances. However, if there are omitted variables that are positively correlated with remittances, such as an unobserved negative income shock ${ }^{5}$, then the impact of remittances would be overestimated.

As a robustness check, we also estimate regressions where the dependent variable is the number of labor hours supplied in the 14 days prior to the survey. We use a Tobit model to estimate the relationship between the amount of remittances received by a household and the supply of labor hours by individual household members. The Tobit model allows us to account for the zero-values of labor hours.

$$
Y_{i j n k}=\alpha_{k}+\lambda R_{j}+C_{i} \theta+Z_{n} \mu+\varepsilon_{i j n k}
$$

with $\varepsilon_{i} \sim \operatorname{Normal}\left(0, \delta^{2}\right)$ and

$$
Y_{i j n k}=\max \left(0, Y_{i j n k}^{*}\right)
$$

where $Y_{i j n k}$ is the number of labor hours worked in the last week by a household member aged 16-65. The variables in vectors $R, Z$ and $C$ are as listed above. All regressions include district-level fixed-effects.

\section{First stage equation: the effect of migration networks on remittances}

As noted in studies that examine the effect of migration or remittances on labor market outcomes at a household level, the likely endogeneity between migration and remittances may present challenges to the estimation approach outlined above. The decision to migrate may be correlated with unobserved household or individual characteristics that are also correlated with the outcome of interest. Thus, a household member may decide to migrate if she/he cannot find a job. Similarly, a migrant who is residing abroad may send more money home if one of the household members loses his/her job (e.g. Yang and Choi 2007). Thus, in the OLS estimation of the effect of remittances on labor market outcomes, the estimated coefficient of interest may be biased. To deal with this problem, we employ two-stage least squares procedure where we instrument ln (remittances) using a variable that predicts the level of remittances but does not have an impact on the outcome of interest other than through remittances. 
Many potential instruments for remittances are likely to be correlated with labor market outcomes. For example, people may migrate away from areas with poor labor market conditions. In the context of armed conflict, people may migrate from areas where infrastructure was destroyed the most and the likelihood of further investment in local industry and other forms of employment is lower.

An instrument must satisfy two restrictions. First, it should be relevant: in other words, the variation in the instrument must be related to the variation in the instrumented variable. Second, the instrument must satisfy the exclusion restriction, meaning that it should not be related to the outcome of interest rather than through the instrumented variable (Wooldridge, 2002).

Drawing on a widely used approach (Acosta 2006; Azzarri and Zezza $2011{ }^{6}$; Binzel and Assaad 2011; Chang et al. 2011; Damon 2007; McKenzie and Rapoport 2007; Winters et al. 2001), we use the size of migration network defined at community (the primary sampling unit) level, henceforth network, as our instrumental variable.

At the household level, the correlation between network and the natural logarithm of remittances received is 0.167 and in the overall analytical sample it is 0.198 (both coefficients are significant at the one percent level).

To estimate the effect of remittances on labor market participation, we use a twostage instrumental variable model (2SLS) and compare the results of 2SLS to the standard OLS estimates. In line with the literature, all specifications are estimated with robust standard errors clustered at the district level.

The first stage of the model predicts the amount of remittances the household receives each year.

$$
R_{j n k}=\mu_{1} * \text { Network }_{n k}+Z_{i j n k} \delta+C_{n k} \gamma+\varepsilon_{j n k}
$$

where $R_{j k}$ is the amount of remittances received by a household $j$ in a primary sampling unit $n$ in district $k$ in the last 12 months. Network $k_{n k}$ is the proportion of households in the primary sampling unit $n$ in district $j$ that had migrants. $Z_{i j n k}$ and $C_{n k}$ are defined as above.

We examine the strength of the IV using an F-test and also by examining the Rsquared between regressions that include and exclude the instruments.

\section{Measures of remittances and conflict Measures of remittances}

To account for possible measurement error in the self-reporting of the amount of remittances received we use three measures of remittances. The first measure is a dummy variable that is equal to one if a household receives any remittances. The second measure is the natural logarithm of the amount of remittances received by the household in the past 12 months from all private donors including family members, relatives and neighbors located abroad and in Tajikistan. The third measure is the number of individuals who provided assistance to the household ${ }^{7}$ in the past 12 months (henceforth, remitters) and who lived abroad or in Tajikistan. This measure includes people identified as remitters but for whom the household did not provide the amount received. Using these variables instead of remittances, should help us to capture a possible recall bias and measurement error in the amount of monetary and in-kind transfers reported by households, as it is possible that some households may fail to accurately estimate total amount of remittances. 


\section{Conflict region variable}

Tajikistan was affected by a violent civil war in the 1992-1993 that resulted in a protracted armed conflict that ended only in 1998. The main cause of the war was the struggle for power between the post-communist government of Tajikistan and the United Tajik Opposition (UTO). The government was affiliated with the clans from Kulob (in eastern Khatlon) and Sugd regions. The UTO was at first supported by Gharmis and Pamiris who populate parts of Khatlon, especially the former Kurgan-Tube region; Raions of Republican Subordination (RRS) and Gorno-Badakshon Autonomous Oblast (GBAO) (Capisani 2000). GBAO withdrew its support of the opposition in the early years of the war (Bliss 2010). Prior to the war, GBAO received large amount of food supplies from other regions of Tajikistan. During the 1992-1993, the only road from other parts of Tajikistan to the capital of GBAO, Khorog was blocked by the fighting. This blockade ${ }^{8}$ and massive inflows of refugees amounting between 30,000 and 50,000 people (Bliss 2010: 276) led to severe food shortages and even hunger in the region (Bliss 2010; Nazriev and Sattorov 2005, 2006). The fighting and destruction were concentrated in the southern region Khatlon, especially the western Khatlon, RRS (also known as Direct Rule Districts) and the country-capital Dushanbe (Bliss 2010: pp. 273-275; Nazriev and Sattorov 2005, 2006). In western Khatlon (Kurgan-Tube region) and RRS, whole villages were burned and population destroyed (Bliss 2010: pp. 273-275). Similar to GBAO, the northern region Sugd was relatively unaffected by the 1992-1993 civil war as it is separated from other areas of Tajikistan by a mountainous range.

We expect therefore to observe a significant impact of war exposure on household economic decisions, including the supply of labor and the use of remittances. We explore this effect by introducing a dummy variable that is equal to one if a district (raion) was severely affected by civil war events in 1992-1998 (henceforth, 'conflict region'). The exposure to conflict is based on the individual's residence at the start of the conflict in 1992. The assignment into 'conflict region' district is based on information on the conflict related events ${ }^{9}$ reported by two Russian language newspapers published in Tajikistan ${ }^{10}$, reports by various non-governmental organizations (e.g. Human Rights Watch 1993, 1995), other studies on Tajikistan and two volumes based on the Tajik government documents that chronicle the 1992 and 1993 events on a day by day basis prepared by Nazriev and Sattorov (2005, 2006). We specify 'conflict region' as an indicator variable that is equal to one for all districts in RRS, the capital city of Dushanbe and most of the districts ${ }^{11}$ in Khatlon region. Respectively, all districts in Sugd and GBAO regions are assigned a value of zero. We recognize that the effect of conflict exposure differed across regions and also examine differences in household characteristics, remittances and migration across regions of Tajikistan. We also interact the 'conflict region' dummy with the measures of remittances to examine differences in labor supply responses by regional exposure to the conflict.

\section{Data and preliminary observations \\ Data}

The study uses household and individual data from the 2003 TLSS ${ }^{12}$ survey that contains information on household composition, employment, consumption and expenditure and migration for 4,160 households. The survey is representative at the regional (four regions) and urban/rural levels and has detailed information on monetary and in-kind transfers 
received by each household from family members and institutions. The data were collected by the State Statistical Agency of Tajikistan and the World Bank.

We examine the monetary and in-kind transfers (as remittances are defined in the survey) received in the past 12 months from private donors living abroad or in Tajikistan. About 20.6 percent of the households interviewed in 2003 received such transfers in the last 12 months, with 9.4 percent receiving remittances from abroad. Among remitters who live abroad, 93 percent live in Russia, while the rest resides in Kazakhstan, Uzbekistan, and other countries ${ }^{13}$.

\section{Preliminary observations}

The summary statistics for households by their residence in 'conflict region' and by the geographical region of residence are presented in Tables 2 and 3 respectively. Households in 'conflict region' are about two percentage points more likely to be headed by women and have lower education levels. They are three percentage points less likely to work in the 14 days prior to the survey and four percentage points more likely to be unemployed at the time of the survey (these differences are statistically significant at the one percent level). Household heads in 'conflict region' are less likely to be married (significant at the 10 percent level). Their monthly earnings are similar across the regions and average about 30 somoni per month with most of the earnings paid in cash. Ten percent of household heads in 'conflict regions' and eight percent of household heads 'non-conflict regions' migrated abroad for at least three months since 1998. They spent 4.74 and 3.73 months abroad in 1998-2003 respectively (the differences are statistically significant at the one and five percent level).

Households in 'conflict regions' are larger and have more children under six years old, and children ages 7-15 compared to households in the rest of Tajikistan. The differences are statistically significant at the one percent level. Households in 'conflict region' were 3 percentage points more likely to have migrants who lived abroad for at least three months since 1998 (differences are significant at the one percent level). Looking at the community characteristics, districts that were more affected by the conflict on an average have higher sex ratios of men to women based on the 1989 and 2000 census data.

Table 3 examines household characteristics according to the household's residence in one of administrative regions of Tajikistan: the capital city Dushanbe, and the regions of Sugd, Khatlon, RRS and GBAO. In this analysis we split Khatlon region into Kulob and Kurgan-Tube zones as they were two the distinct oblasts (regions) before the 1990 ${ }^{15}$. Kurgan-Tube group of districts suffered from a greater amount of damage according to events described in Nazriev and Sattorov $(2005,2006)$.

In Dushanbe 32 percent of household heads are female compared to 20 percent in RRS, 19 percent in Sugd, 17 percent in Kurgan-Tube and 14 and 13 percent in GBAO and Kulob zones respectively. Household heads in Dushanbe are also younger, only 61 percent of them work, and they have significantly higher earnings than household heads from the rest of Tajikistan. Further, households in RRS, Kurgan-Tube and Kulob have the largest number of children under six years old, and ages 7-15, highest dependency ratios and larger households, e.g. 7.6 in RRS vs. 4.5 household members in Dushanbe. 
Table 2 Household demographic characteristics

\begin{tabular}{|c|c|c|c|c|}
\hline Variable & $\begin{array}{l}\text { Full } \\
\text { sample }\end{array}$ & $\begin{array}{l}\text { Non conflict } \\
\text { region }\end{array}$ & $\begin{array}{l}\text { Conflict } \\
\text { region }\end{array}$ & $\begin{array}{l}\text { Difference in } \\
\text { means (2)-(3) }\end{array}$ \\
\hline & (1) & (2) & (3) & (4) \\
\hline \multicolumn{5}{|l|}{ Household head characteristics } \\
\hline Age, years & 48.88 & 48.67 & 49.01 & -0.34 \\
\hline $\mathrm{HH}$ head is female (indicator) & 0.20 & 0.18 & 0.21 & $-0.02 * * *$ \\
\hline Married (indicator) & 0.77 & 0.78 & 0.77 & $0.01^{*}$ \\
\hline Education & 11.07 & 11.28 & 10.93 & $0.36^{* * *}$ \\
\hline Worked last 14 days (indicator) & 0.67 & 0.69 & 0.66 & $0.03 * * *$ \\
\hline In the workforce (indicator) & 0.70 & 0.73 & 0.68 & $0.05 * * *$ \\
\hline Not employed last 14 days (indicator) & 0.29 & 0.27 & 0.31 & $-0.04 * * *$ \\
\hline Total monthly earnings (all types), somoni & 30.49 & 31.34 & 29.93 & 1.41 \\
\hline Monthly wages (monetary), somoni & 28.93 & 28.82 & 29.00 & -0.18 \\
\hline Migrated abr for 3+ months since 1998 & 0.09 & 0.08 & 0.10 & $-0.02 * * *$ \\
\hline Mean number of months spent abroad & 4.31 & 3.73 & 4.74 & $-1.01 * *$ \\
\hline \multicolumn{5}{|l|}{ Household characteristics } \\
\hline Household size & 6.38 & 5.90 & 6.68 & $-0.78 * * *$ \\
\hline $\begin{array}{l}\text { Dependents (under } 16 \& 66+\text { )/ } \\
\text { (Adults 16-65) }\end{array}$ & 1.02 & 0.89 & 1.10 & $-0.22 * * *$ \\
\hline $\mathrm{N}$ of children ages $0-6$ & 1.14 & 0.97 & 1.25 & $-0.28^{* * *}$ \\
\hline $\mathrm{N}$ of children ages $7-15$ & 1.49 & 1.25 & 1.65 & $-0.40 * * *$ \\
\hline $\mathrm{N}$ of elderly 66 and above & 0.24 & 0.24 & 0.24 & -0.01 \\
\hline In (non-wage income) & 0.95 & 0.95 & 0.95 & $0.00 * * *$ \\
\hline Adults age $16-65$ in a household & 3.50 & 3.44 & 3.54 & -0.09 \\
\hline $\mathrm{N}$ currently at home migrants & 0.27 & 0.23 & 0.29 & $-0.05^{* *}$ \\
\hline $\begin{array}{l}\text { has a migrant who was abr for } \\
3+\text { months since } 1998\end{array}$ & 0.20 & 0.17 & 0.21 & $-0.04 * * *$ \\
\hline \multicolumn{5}{|l|}{ Community characteristics } \\
\hline SR: all men to women in 1989 & 1.01 & 0.97 & 1.03 & $-0.05^{* * *}$ \\
\hline SR: all men to women in 2000 & 1.00 & 1.00 & 1.01 & $-0.01 * * *$ \\
\hline SR: men to women age 15-64 in 1989 & 1.00 & 0.97 & 1.03 & $-0.06^{* * *}$ \\
\hline SR: men to women age $15-64$ in 2000 & 0.99 & 0.99 & 1.00 & $-0.01 * * *$ \\
\hline $\begin{array}{l}\text { Proportion of households with } \\
\text { migrants in psu }\end{array}$ & 0.20 & 0.17 & 0.21 & $-0.04 * * *$ \\
\hline Kulob & 0.09 & 0.03 & 0.13 & \\
\hline Kurgan-Tube & 0.21 & 0.00 & 0.34 & \\
\hline Sugd & 0.35 & 0.90 & 0.00 & \\
\hline GBAO & 0.03 & 0.08 & 0.00 & \\
\hline RRS & 0.19 & 0.00 & 0.32 & \\
\hline Dushanbe & 0.13 & 0.00 & 0.22 & \\
\hline $\mathrm{N}$ & 4160 & 1780 & 2380 & \\
\hline
\end{tabular}

Notes: ${ }^{*}$ significant at $10 \% ;{ }^{* *}$ significant at $5 \% ;{ }^{* * *}$ significant at $1 \%$. Estimates are weighted by inverse sampling probability. 'SR' stands for sex ratio, 'workforce' - includes employed and actively looking for work individuals. Data source: Authors calculations using data from TLSS (2003). 'Conflict region' as defined in sub-section "Conflict region variable". Sex ratios were calculated population data collected by the State Statistical Committee (2002). 
Table 3 Household demographic characteristics by region of residence

\begin{tabular}{|c|c|c|c|c|c|c|}
\hline Variable & $\begin{array}{l}\text { GBAO } \\
(1)\end{array}$ & $\begin{array}{l}\text { Sugd } \\
(2)\end{array}$ & $\begin{array}{l}\text { Kurgan } \\
\text { (3) }\end{array}$ & $\begin{array}{l}\text { Kulob } \\
\text { (4) }\end{array}$ & $\begin{array}{l}\text { Dushanbe } \\
\text { (5) }\end{array}$ & $\begin{array}{l}\text { RRS } \\
\text { (6) }\end{array}$ \\
\hline \multicolumn{7}{|l|}{ Household head characteristics } \\
\hline Age, years & 50.73 & 48.47 & 48.14 & 51.08 & 46.16 & 50.92 \\
\hline $\mathrm{HH}$ head is female (indicator) & 0.14 & 0.19 & 0.17 & 0.13 & 0.32 & 0.20 \\
\hline Married (indicator) & 0.82 & 0.77 & 0.82 & 0.83 & 0.66 & 0.78 \\
\hline Education & 11.66 & 11.27 & 10.66 & 10.59 & 12.25 & 10.42 \\
\hline Worked last 14 days (indicator) & 0.76 & 0.68 & 0.72 & 0.65 & 0.61 & 0.64 \\
\hline In the workforce (indicator) & 0.77 & 0.72 & 0.73 & 0.66 & 0.66 & 0.65 \\
\hline Not employed last 14 days (indicator) & 0.22 & 0.27 & 0.27 & 0.34 & 0.32 & 0.31 \\
\hline Total monthly earnings (all types), somoni & 26.46 & 31.17 & 23.73 & 32.48 & 50.92 & 22.33 \\
\hline Monthly wages (monetary), somoni & 25.83 & 28.40 & 22.80 & 31.76 & 49.92 & 21.39 \\
\hline Migrated abr for 3+ months since 1998 & 0.04 & 0.09 & 0.07 & 0.03 & 0.10 & 0.17 \\
\hline Mean number of months spent abroad & 5.64 & 3.17 & 2.15 & 0.62 & 3.13 & 10.61 \\
\hline \multicolumn{7}{|l|}{ Household characteristics } \\
\hline Household size & 6.33 & 5.80 & 7.01 & 7.10 & 4.59 & 7.63 \\
\hline Dependents (under 16 \& 66+)/(Adults 16-65) & 0.91 & 0.87 & 1.22 & 1.21 & 0.89 & 1.08 \\
\hline$N$ of children ages $0-6$ & 0.90 & 0.96 & 1.35 & 1.40 & 0.81 & 1.40 \\
\hline $\mathrm{N}$ of children ages $7-15$ & 1.29 & 1.22 & 1.88 & 1.73 & 1.03 & 1.82 \\
\hline $\mathrm{N}$ of elderly 66 and above & 0.30 & 0.23 & 0.20 & 0.30 & 0.16 & 0.31 \\
\hline Ln (non-wage income) & 1.41 & 0.92 & 0.82 & 1.05 & 0.84 & 1.11 \\
\hline Adults age $16-65$ in a household & 3.83 & 3.39 & 3.58 & 3.67 & 2.59 & 4.10 \\
\hline $\mathrm{N}$ currently at home migrants & 0.24 & 0.24 & 0.19 & 0.06 & 0.19 & 0.54 \\
\hline has a migrant who was abr for 3+ months since 1998 & 0.15 & 0.18 & 0.14 & 0.05 & 0.15 & 0.39 \\
\hline \multicolumn{7}{|l|}{ Community characteristics } \\
\hline SR: all men to women in 1989 & 1.04 & 0.97 & 0.99 & 0.98 & 0.96 & 1.12 \\
\hline SR: all men to women in 2000 & 1.02 & 1.00 & 1.00 & 0.98 & 1.03 & 1.01 \\
\hline SR: men to women age 15-64 in 1989 & 1.04 & 0.96 & 0.98 & 0.96 & 1.00 & 1.12 \\
\hline SR: men to women age 15-64 in 2000 & 1.02 & 0.99 & 0.99 & 0.94 & 1.03 & 1.01 \\
\hline Proportion of households with migrants in psu & 0.15 & 0.18 & 0.14 & 0.05 & 0.15 & 0.39 \\
\hline $\mathrm{N}$ & 480 & 1260 & 740 & 320 & 660 & 700 \\
\hline
\end{tabular}

Notes: * significant at $10 \%$; $*$ significant at $5 \% ;{ }^{* *}$ significant at $1 \%$. Estimates are weighted by inverse sampling probability. 'Kurgan' and 'Kulob' stand for districts in Kurgan-Tube and Kulob zones respectively that are defined in ft. 15. 'SR' stands for sex ratio, 'workforce' - includes employed and actively looking for work individuals. Data source: as for Table 2.

In RRS, Dushanbe, Sugd and Kurgan-Tube zone respectively, 17, 10, 9 and 7 percent of household heads migrated for work abroad for 3 months and more, followed by a much smaller percentage in GBAO and Kulob. The longest period abroad between 1998 and 2003 was spent by household heads from RRS and GBAO at 10.6 and 5.6 months respectively. Households from Kulob have the lowest number of migrants currently at home and of these who have ever migrated abroad in 1998-2003 at 0.06 persons and 0.05 persons respectively. These numbers are almost three times lower than these for other regions. Households in RRS region had 0.54 migrants currently at home and 0.39 migrants who have ever been abroad for at least 3 months and more since 1998. These numbers suggest interesting dynamics. While most of the districts in the Kulob zone are included in the definition of 'conflict region', the migration patterns there are substantially different than 
the patterns in Kurgan-Tube or RRS groups of districts which are also included in the 'conflict region'. One of the main differences between the two regions is that the "Kulobi" (clans from Kulob district) were on the winning side in the war (Bliss 2010) and members of Kulobi clans were less likely to migrate abroad for the fear of retribution as suggested by Tadjbakhsh (1996). Some Gharmis (people from Gharm districts in RRS and some communities in Kurgan-Tube) were fighting against Kulobis in the war, and in the postconflict period had difficulties with employment as they were viewed 'guilty' by association. Men who ventured outside of their villages and houses were subject to beatings and persecution by the police (Human Rights Watch 1995). These difficulties may have induced them to look for jobs elsewhere.

Table 4 presents summary statistics on remittances by the type of donor (private and institutional), type of transfer (monetary or in-kind) and donor's location (in Tajikistan or abroad). The number suggest that households in 'conflict region' receive larger amounts of in-kind transfers from Tajikistan, monetary remittances from abroad and larger amounts of in-kind institutional transfers from Tajikistan (significant at least at

Table 4 Migration and remittance descriptive statistics

\begin{tabular}{|c|c|c|c|c|}
\hline Variable & $\begin{array}{l}\text { Full } \\
\text { sample }\end{array}$ & $\begin{array}{l}\text { Non conflict } \\
\text { region }\end{array}$ & $\begin{array}{l}\text { Conflict } \\
\text { region }\end{array}$ & $\begin{array}{l}\text { Difference in } \\
\text { means (2)-(3) }\end{array}$ \\
\hline & (1) & (2) & (3) & (4) \\
\hline \multicolumn{5}{|l|}{ Private remittances } \\
\hline Monetary remittances from TJ & 33.61 & 34.46 & 33.05 & 1.41 \\
\hline In-kind remittances from TJ & 10.38 & 8.78 & 11.40 & $-2.62 * *$ \\
\hline Total private remittances from $T J$ & 43.98 & 43.24 & 44.45 & -1.21 \\
\hline Monetary remittances from abroad & 62.88 & 53.45 & 68.93 & $-15.48 *$ \\
\hline In-kind remittances from abroad & 1.78 & 1.92 & 1.69 & 0.23 \\
\hline Total private remittances from abroad & 64.66 & 55.37 & 70.62 & $-15.25 *$ \\
\hline N of private donors in Tajikistan & 0.14 & 0.13 & 0.14 & -0.01 \\
\hline $\mathrm{N}$ of private donors abroad & 0.10 & 0.10 & 0.10 & $0.00 *$ \\
\hline \multicolumn{5}{|l|}{ Institutional remittances } \\
\hline Monetary remittances from TJ & 0.18 & 0.09 & 0.24 & -0.14 \\
\hline In-kind institutional remittances from TJ & 3.22 & 1.08 & 4.59 & $-3.52 * * *$ \\
\hline Total institutional remittances from $T J$ & 3.40 & 1.17 & 4.83 & $-3.66 * * *$ \\
\hline Monetary remittances from abroad & 1.70 & 0.10 & 2.73 & $-2.64 *$ \\
\hline In-kind institutional remittances from abroad & 15.54 & 28.17 & 7.43 & $20.75^{* * *}$ \\
\hline Total institutional remittances from abroad & 17.24 & 28.27 & 10.16 & $18.11^{* * *}$ \\
\hline $\mathrm{N}$ of donors-institutions in Tajikistan & 0.04 & 0.02 & 0.05 & $-0.04 * * *$ \\
\hline $\mathrm{N}$ of donors-institutions abroad & 0.12 & 0.21 & 0.07 & $0.14^{* * *}$ \\
\hline \multicolumn{5}{|l|}{ Overall } \\
\hline Dummy for a private donor, any & 0.20 & 0.20 & 0.20 & 0.00 \\
\hline Dummy for donor-hh head/spouse & 0.05 & 0.06 & 0.05 & 0.00 \\
\hline Number of institutional donors & 0.16 & 0.23 & 0.12 & $0.11^{* * *}$ \\
\hline Dummy variable for donor-institution & 0.16 & 0.21 & 0.12 & $0.09 * * *$ \\
\hline All private remittances, $\mathrm{TJ}+\mathrm{abr}$ & 110.05 & 99.31 & 116.95 & $-17.64 * *$ \\
\hline All institutional remittances, $\mathrm{TJ}+\mathrm{abr}$ & 20.70 & 29.60 & 14.99 & $14.61 * * *$ \\
\hline $\mathrm{N}$ & 4160 & 1780 & 2380 & \\
\hline
\end{tabular}


Table 5 Migration and remittance descriptive statistics by households' region of residence

\begin{tabular}{lllllll}
\hline Variable & GBAO & Sugd & Kurgan & Kulob & Dushanbe & RRS \\
\hline & $(1)$ & $(2)$ & $(3)$ & $(4)$ & $(5)$ & $(6)$ \\
\hline Private remittances & & & & & & \\
\hline Monetary remittances from TJ & 10.45 & 35.11 & 25.88 & 56.09 & 56.50 & 16.92 \\
\hline In-kind private remittances from TJ & 2.52 & 8.86 & 8.37 & 22.73 & 19.56 & 4.60 \\
\hline Total private remittances from TJ & 12.97 & 43.96 & 34.25 & 78.82 & 76.06 & 21.52 \\
\hline Monetary remittances from abroad & 46.98 & 55.70 & 19.47 & 25.24 & 63.90 & 140.65 \\
\hline In-kind private remittances from abroad & 0.71 & 2.08 & 0.12 & 0.00 & 2.31 & 3.60 \\
\hline Total private remittances from abroad & 47.69 & 57.79 & 19.59 & 25.24 & 66.21 & 144.25 \\
\hline N of private donors in Tajikistan & 0.10 & 0.13 & 0.14 & 0.22 & 0.20 & 0.08 \\
\hline N of private donors abroad & 0.16 & 0.10 & 0.05 & 0.04 & 0.10 & 0.16 \\
\hline Institutional remittances & & & & & & \\
\hline Monetary remittances from TJ & 0.00 & 0.10 & 0.00 & 0.00 & 0.00 & 0.73 \\
\hline In-kind institutional remittances from TJ & 0.96 & 1.12 & 6.06 & 0.25 & 3.12 & 5.76 \\
\hline Total institutional remittances from TJ & 0.96 & 1.22 & 6.06 & 0.25 & 3.12 & 6.49 \\
\hline Monetary remittances from abroad & 0.07 & 0.06 & 3.05 & 2.94 & 0.08 & 4.01 \\
\hline In-kind institutional remittances from abroad & 203.68 & 12.96 & 9.83 & 21.18 & 2.01 & 3.94 \\
\hline Total institutional remittances from abroad & 203.75 & 13.03 & 12.88 & 24.12 & 2.10 & 7.95 \\
\hline N of donors-institutions in Tajikistan & 0.01 & 0.02 & 0.02 & 0.01 & 0.07 & 0.09 \\
\hline N of donors-institutions abroad & 1.07 & 0.13 & 0.08 & 0.18 & 0.04 & 0.06 \\
\hline Overall & & & & & & \\
\hline Dummy for a private donor, any & 0.23 & 0.20 & 0.17 & 0.19 & 0.23 & 0.22 \\
\hline Dummy for donor-hh head/spouse & 0.03 & 0.06 & 0.04 & 0.02 & 0.07 & 0.07 \\
\hline Number of institutional donors & 1.08 & 0.15 & 0.10 & 0.18 & 0.11 & 0.15 \\
\hline Dummy variable for donor-institution & 0.96 & 0.14 & 0.10 & 0.18 & 0.11 & 0.15 \\
\hline All private remittances, TJ+abr & 62.95 & 102.33 & 53.98 & 107.28 & 147.90 & 166.22 \\
\hline All institutional remittances, TJ+abr & 204.71 & 14.43 & 18.94 & 24.37 & 5.22 & 14.44 \\
\hline N & 480 & 1260 & 740 & 320 & 660 & 700 \\
\hline Notes: sign & & & & & \\
\hline
\end{tabular}

Notes: * significant at $10 \%$; ${ }^{* *}$ significant at $5 \%$; $* * *$ significant at $1 \%$.

Estimates are weighted by inverse sampling probability. 'Kurgan' and 'Kulob' stand for districts in Kurgan-Tube and Kulob zones respectively that are defined in ft. 15. Data source: Authors' calculations using TLSS (2003).

the 10 percent level). However, households in the rest of Tajikistan received larger amounts of in-kind remittances from institutional donors located abroad. In overall, households in 'conflict region' received 17.6 somoni more per year from private donors and 14.6 somoni less from institutional donors (all sources and types of income) than households in regions less affected by conflict (the differences are statistically significant at least at the 5 percent level).

Examining remittances and other transfers by region of residence (Table 5), we can see that the remittances in the 'conflict region' are driven by the sample of households in the RRS region and Dushanbe, who received the largest amount of remittances from abroad at 166.22 and 147.90 somoni per year. Kulobi residents received 107.3 somoni in remittances, with 73 percent of remittances coming from Tajikistan, while in Dushanbe and RRS remittances from Tajikistan represented only 51 percent and 13 percent of the total private remittances. GBAO was the leader in institutional remittances with households on an average receiving 204.71 somoni per year. Other regions received eight (Kulob zone) to 39 (Dushanbe) times less from institutional sources compared to GBAO. High institutional transfers reported by households 
in this region may be explained by the involvement in the economic development in GBAO by the Aga-Khan Foundation (AKF) for economic development.

According to Tadjbakhsh (1996), there is a long tradition in Tajikistan, especially in the mountains of Gharm (located in RRS), to diversify household income by sending some of the household members abroad. Our data supports her observation, as households in RRS report the largest amounts of remittances from abroad and this region is a home to larger migration networks. Recent research suggests that migrants who have access to an established migrant network in the migrant-receiving countries are more likely to have access to jobs than individuals who did not have access to such networks (Munshi 2003; Beaman 2012).

In Table 6, we estimate the effect of household level characteristics on the level of remittances. Remittances are negatively associated with age and education level of the household's head and are higher for households headed by women. They are also positively associated with non-wage income received by the household. The estimated coefficients are statistically significant at least at the 5 percent level. Among the community-level covariates (Columns 2-7), the size of migration network is consistently positively associated with remittances. Regional dummy variables have no statistically significant association with remittances when we control for other household and community characteristics (Column 6). District-level sex ratio of men to women in 1989 is also positively associated with remittances, this variable drops out of the estimation when we add fixed effects at the district level (Column 7), while the estimated coefficients on all other covariates remain stable.

Figures 1 and 2 present average employment rates and hours worked by men and women by their age and household's remittance receiving status. The summary statistics for the analytical sample are shown in Table 12 in Appendix. The receipt of remittances appears to have a significant impact on labor supply of men and women aged 16-65. Men from remittance-receiving households are less likely to be employed (Figure 1, top panel). Further, conditional on employment, women 16-50 in the remittance-receiving households work fewer hours than those in households that do not receive remittances (Figure 2, bottom panel).

These descriptive results suggest that there could be significant differences in individual labor force participation and labor hours supplied based on the householdremittance receiving status and residence in conflict 'region'. The following section explores these relationships in an econometric framework.

\section{Empirical results}

\section{Employment}

Table 7 reports results of the OLS regressions where the dependent variable is whether an individual was employed in the 14 days prior to the survey ${ }^{16}$. All regressions include controls for age, age squared, education level, non-wage income, household dependency ratio, indicators for an individual being married, female household head, rural residence dummy and fixed effects at the district level.

In Panel A we present results for men. Column 1 presents the baseline model results, where $\ln$ (total private remittances) is the main variable of interest ${ }^{17}$. In Column 2 , we add an interaction term between the $\ln$ (remittances) and the 'conflict region' dummy variable. In columns 3-4 we replace the $\ln$ (remittances) with a dummy variable for a household receiving any remittances. In Columns 5 and 6, we replace ln (remittances) 
Table 6 Correlates of private remittances at a household level

\begin{tabular}{|c|c|c|c|c|c|c|c|}
\hline & $(1)$ & $(2)$ & (3) & $(4)$ & $(5)$ & (6) & $(7)$ \\
\hline & OLS & OLS & OLS & OLS & OLS & OLS & FE \\
\hline \multirow[t]{2}{*}{ Age } & $-0.020^{* * *}$ & $-0.019^{* * *}$ & $-0.018^{* * *}$ & $-0.019^{* * *}$ & $-0.018^{* * *}$ & $-0.019^{* * *}$ & $-0.019^{* * *}$ \\
\hline & $(0.004)$ & $(0.004)$ & $(0.004)$ & $(0.004)$ & $(0.004)$ & $(0.004)$ & $(0.004)$ \\
\hline \multirow[t]{2}{*}{ Years of education completed } & $-0.088^{* * *}$ & $-0.087^{* * *}$ & $-0.075^{* * *}$ & $-0.087^{* * *}$ & $-0.075^{* * *}$ & $-0.079^{* * *}$ & $-0.079^{* * *}$ \\
\hline & $(0.012)$ & $(0.012)$ & $(0.011)$ & $(0.011)$ & $(0.011)$ & $(0.011)$ & $(0.011)$ \\
\hline \multirow[t]{2}{*}{ Married } & 0.197 & 0.207 & 0.169 & 0.191 & 0.167 & 0.164 & 0.121 \\
\hline & $(0.189)$ & $(0.188)$ & $(0.188)$ & $(0.189)$ & $(0.188)$ & $(0.188)$ & $(0.182)$ \\
\hline \multirow[t]{2}{*}{ Rural } & -0.28 & -0.175 & $-0.368^{* *}$ & $-0.302^{*}$ & $-0.375^{* *}$ & -0.276 & -0.445 \\
\hline & $(0.170)$ & $(0.183)$ & $(0.160)$ & $(0.169)$ & $(0.159)$ & $(0.185)$ & $(0.273)$ \\
\hline \multirow[t]{2}{*}{ Household size } & 0.026 & 0.026 & 0.012 & 0.025 & 0.012 & 0.014 & 0.023 \\
\hline & $(0.018)$ & $(0.017)$ & $(0.017)$ & $(0.018)$ & $(0.017)$ & $(0.018)$ & $(0.017)$ \\
\hline \multirow{2}{*}{$\begin{array}{l}\text { Dependents (under } 16 \\
+66 \& \text { \&above)/Adults 16-65) } \\
\end{array}$} & $-0.109^{* *}$ & $-0.096^{*}$ & -0.068 & $-0.109^{* *}$ & -0.070 & -0.072 & -0.076 \\
\hline & $(0.054)$ & $(0.054)$ & $(0.055)$ & $(0.054)$ & $(0.055)$ & $(0.054)$ & $(0.054)$ \\
\hline \multirow[t]{2}{*}{ Household head is female } & $0.420^{* *}$ & $0.409^{* *}$ & $0.434^{* * *}$ & $0.426^{* * *}$ & $0.436^{* * *}$ & $0.466^{* * *}$ & $0.450^{* * *}$ \\
\hline & $(0.160)$ & $(0.161)$ & $(0.156)$ & $(0.159)$ & $(0.156)$ & $(0.156)$ & $(0.149)$ \\
\hline \multirow[t]{2}{*}{ In (non-wage income) } & $0.105^{* * *}$ & $0.101^{* * *}$ & $0.093^{* * *}$ & $0.102^{* * *}$ & $0.092^{* * *}$ & $0.083^{* *}$ & $0.076^{* *}$ \\
\hline & $(0.037)$ & $(0.037)$ & $(0.035)$ & $(0.037)$ & $(0.035)$ & $(0.035)$ & $(0.036)$ \\
\hline \multirow[t]{2}{*}{ Conflict region } & -0.092 & -0.216 & -0.174 & -0.108 & -0.178 & -0.235 & \\
\hline & $(0.136)$ & $(0.167)$ & $(0.125)$ & $(0.135)$ & $(0.124)$ & $(0.365)$ & \\
\hline \multirow[t]{2}{*}{ In distance to regional center } & & -0.064 & & & & & \\
\hline & & $(0.040)$ & & & & & \\
\hline \multirow{2}{*}{$\begin{array}{l}\text { Proportion of households with } \\
\text { migrants in psu }\end{array}$} & & & $2.087^{* * *}$ & $2.034^{* * *}$ & $2.447^{* * *}$ & $2.829^{* * *}$ & \\
\hline & & & $(0.317)$ & $(0.324)$ & $(0.411)$ & $(0.525)$ & \\
\hline \multirow{2}{*}{$\begin{array}{l}\text { Sex Ratio: all men to women in } \\
1989\end{array}$} & & & & $0.376^{* * *}$ & $0.155^{* *}$ & $0.148^{* * *}$ & \\
\hline & & & & $(0.055)$ & $(0.059)$ & $(0.048)$ & \\
\hline \multirow[t]{3}{*}{ Resident of } & & & & & & 0.316 & \\
\hline & & & & & & & \\
\hline & & & & & & $(0.193)$ & \\
\hline \multirow[t]{2}{*}{ Dushanbe } & & & & & & 0.347 & \\
\hline & & & & & & $(0.402)$ & \\
\hline \multirow[t]{2}{*}{ Kulob } & & & & & & 0.579 & \\
\hline & & & & & & $(0.364)$ & \\
\hline \multirow[t]{2}{*}{ Kurgan-Tube } & & & & & & 0.098 & \\
\hline & & & & & & $(0.407)$ & \\
\hline \multirow[t]{2}{*}{ RRS } & & & & & & -0.152 & \\
\hline & & & & & & $(0.389)$ & \\
\hline \multirow[t]{2}{*}{ Constant } & $2.853^{* * *}$ & $2.984^{* * *}$ & $2.438^{* * *}$ & $2.486^{* * *}$ & $2.297^{* * *}$ & $2.117^{* * *}$ & $2.279^{* * *}$ \\
\hline & $(0.362)$ & $(0.384)$ & $(0.381)$ & $(0.371)$ & $(0.383)$ & $(0.366)$ & $(0.382)$ \\
\hline $\mathrm{N}$ & 4061 & 4061 & 4061 & 4061 & 4061 & 4061 & 4061 \\
\hline R squared & 0.03 & 0.03 & 0.06 & 0.03 & 0.06 & 0.07 & 0.05 \\
\hline Adjusted $R$ squared & 0.03 & 0.03 & 0.06 & 0.03 & 0.06 & 0.06 & 0.05 \\
\hline
\end{tabular}




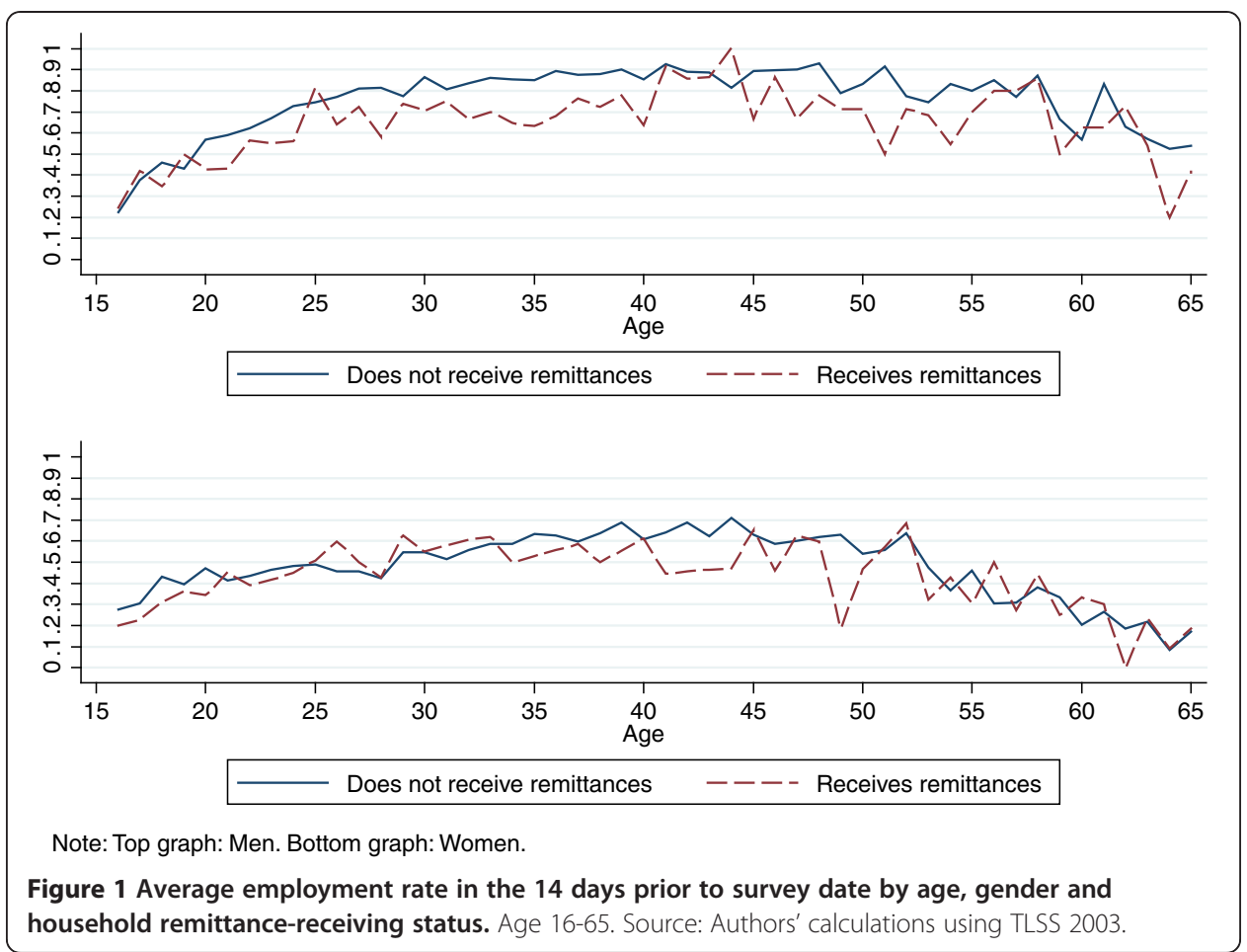

with two variables controlling for the number of private remitters located abroad and in Tajikistan. We then repeat this analysis for women and present results in Panel B.

The estimated coefficients on the natural logarithm of annual remittances and the dummy variable for a household receiving remittances are negative and statistically significant (Columns 1, 3, 7 and 9). Men and women from remittance-receiving households are 8.6 and 4.4

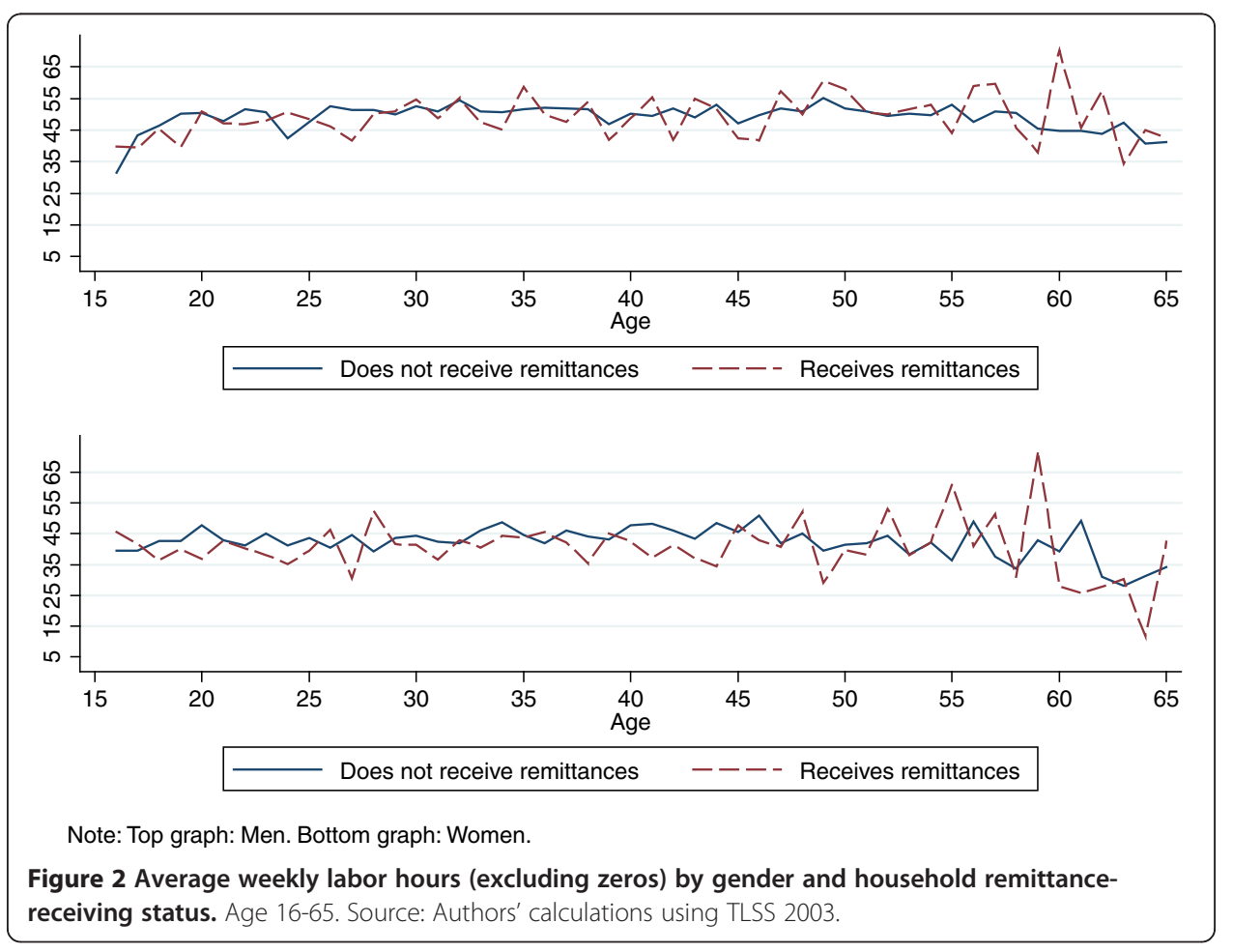


Table 7 Employment, remittances and conflict

\begin{tabular}{|c|c|c|c|c|c|c|c|c|c|c|c|c|}
\hline & \multicolumn{6}{|c|}{ Panel A: Men } & \multicolumn{6}{|c|}{ Panel B: Women } \\
\hline & (1) & $(2)$ & (3) & (4) & (5) & (6) & (7) & (8) & (9) & (10) & (11) & (12) \\
\hline \multirow[t]{2}{*}{ Ln(total remittances from abroad \& Tajikistan) } & $-0.015^{* * *}$ & $-0.010^{*}$ & & & & & $-0.008^{* * *}$ & -0.002 & & & & \\
\hline & $(0.003)$ & $(0.005)$ & & & & & $(0.003)$ & $(0.004)$ & & & & \\
\hline \multirow[t]{2}{*}{ Conflict region*Ln(total remittances) } & $-0.009-$ & & & & & & & $0.010^{* *}$ & & & & \\
\hline & $(0.007)$ & & & & & & & $(0.005)$ & & & & \\
\hline \multirow[t]{2}{*}{ Receives remittances (dummy) } & & & $-0.086^{* * *}$ & $-0.061^{* *}$ & & & & & $-0.044^{* * *}$ & -0.006 & & \\
\hline & & & $(0.020)$ & $(0.028)$ & & & & & $(0.016)$ & $(0.023)$ & & \\
\hline \multirow[t]{2}{*}{ Conflict region*Receives remittances } & & & & -0.048 & & & & & & $-0.065^{* *}$ & & \\
\hline & & & & $(0.039)$ & & & & & & $(0.030)$ & & \\
\hline \multirow[t]{2}{*}{$\mathrm{N}$ of private remitters abroad } & & & & & $-0.081^{* * *}$ & -0.035 & & & & & -0.028 & -0.001 \\
\hline & & & & & $(0.026)$ & $(0.034)$ & & & & & $(0.017)$ & $(0.021)$ \\
\hline \multirow[t]{2}{*}{$\mathrm{N}$ of private remitters in Tajikistan } & & & & & $-0.039^{* *}$ & -0.04 & & & & & $-0.032^{* *}$ & -0.009 \\
\hline & & & & & $(0.016)$ & $(0.027)$ & & & & & $(0.014)$ & $(0.021)$ \\
\hline \multirow[t]{2}{*}{ Conflict region*N remitters abroad } & & & & & & $-0.085^{*}$ & & & & & & -0.047 \\
\hline & & & & & & $(0.047)$ & & & & & & $(0.032)$ \\
\hline \multirow[t]{2}{*}{ Conflict region*N remitters in Tajikistan } & & & & & & 0.003 & & & & & & -0.035 \\
\hline & & & & & & $(0.033)$ & & & & & & $(0.028)$ \\
\hline $\bar{N}$ & 6552 & 6552 & 6552 & 6552 & 6552 & 6552 & 7351 & 7351 & 7351 & 7351 & 7351 & 7351 \\
\hline R squared & 0.20 & 0.20 & 0.20 & 0.20 & 0.20 & 0.20 & 0.11 & 0.11 & 0.11 & 0.11 & 0.11 & 0.11 \\
\hline
\end{tabular}

OLS models. Dependent variable: employed in the last 14 days.

Notes: * significant at $10 \%$; ** significant at $5 \%$; *** significant at $1 \%$. All regressions control for age, age squared, education level, non-wage income, household dependency ratio, indicators for being married, female household head and rural residence, and a constant term. All regressions include district-level fixed effects. Robust standard errors in parenthesis.

Source: as for Table 2. 
percentage points less likely to be employed compared to men and women who live in households without remittances. Both effects are significant at the one percent level.

Individuals from households who have remitters abroad and in Tajikistan are also less likely to be employed (Columns 5 and 11). The effect is again higher for men. The probability of male employment declines by 8.1 percentage points for each additional remitter living abroad (significant at the 1 percent level), and by 3.9 percentage points (significant at the 5 percent level) for each additional remitter in Tajikistan. Having a remitter abroad does not have a statistically significant impact on female employment. However, having access to one additional remitter in Tajikistan reduces women' employment by 3.2 percentage points (Column 11). This result is significant at the 5 percent level. The estimated coefficients for the number of remitters abroad or in Tajikistan are not statistically significantly different from each other (Columns 5 and 11) in the regressions for men and women. However, we present separate results for remitters who live in Tajikistan and abroad, so we can evaluate the impact of funds coming from remitters by their place of residence ${ }^{18}$.

Next, we examine the effect of interactions between 'conflict region' dummy variable and household's remittances measures ${ }^{19}$. The interaction term between 'conflict region' dummy and receipt of remittances is not statistically significantly different from zero in the regressions for men (Columns 2 and 4). In the regressions for the sample of women, both the amount and the fact of receiving remittances have a negative and statistically significant impact on female employment of women in 'conflict region', with the estimated coefficient on the stand-alone remittance variables becoming statistically insignificant.

\section{Tobit regressions - labor hours supply}

As a robustness check, we have also estimated regressions where 'hours worked in the last 14 days' is used as the main dependent variable (Table 8). This variable was obtained from the 2003 TLSS, Module 5, Section B, questions 3 and 5. We use Tobit models to control for the censoring in the dependent variable. As in Table 7, we include controls for individual and household characteristics, rural location and district level fixed effects ${ }^{20}$. The results are reported separately for men and women.

As in Table 7, we observe that measures of remittances have a negative and statistically significant effect on the hours of work reported by both men and women. When we differentiate the analysis by 'conflict region' dummy variable, for men the results do not change. When we consider the female sample, we observe that the estimated coefficients on the stand-alone remittance measures are smaller. The estimated coefficients on the interactions of 'conflict region' dummy and three measures of remittances are mostly not statistically significantly different from zero, except for the interaction term between the 'conflict region' dummy and the number of remitters in Tajikistan.

\section{Instrumental variable estimation}

To account for potential reverse causality between labor supply and remittances, we resort to instrumental variables estimation methods. Table 9 presents results from the IV-2SLS and IV-Tobit regressions where the dependent variable is an individual's employment status, and hours worked in the 14 days prior to the survey, respectively. Panel A presents results for the full sample and Panel B for the sample of individuals from 'conflict region'. The main independent variable of interest is ln (remittances received by households in the past 12 months from household members and abroad 
Table 8 Hours worked, remittances and conflict exposure

\begin{tabular}{|c|c|c|c|c|c|c|c|c|c|c|c|c|}
\hline & \multicolumn{6}{|c|}{ Panel A: Men } & \multicolumn{6}{|c|}{ Panel B: Women } \\
\hline & $(1)$ & $(2)$ & (3) & $(4)$ & $(5)$ & $(6)$ & (7) & $(8)$ & (9) & $(10)$ & (11) & $(12)$ \\
\hline \multirow[t]{2}{*}{ Ln(total remittances from abroad and Tajikistan) } & $-2.046^{* * *}$ & $-2.214^{* * *}$ & & & & & $-1.086^{* * *}$ & -0.612 & & & & \\
\hline & $(0.234)$ & $(0.352)$ & & & & & $(0.253)$ & $(0.398)$ & & & & \\
\hline \multirow[t]{2}{*}{ Conflict region*Ln(total remittances) } & & 0.312 & & & & & & -0.819 & & & & \\
\hline & & $(0.460)$ & & & & & & $(0.514)$ & & & & \\
\hline \multirow[t]{2}{*}{ Receives remittances (dummy) } & & & $-11.769^{* * *}$ & $-13.252^{* * *}$ & & & & & $-6.402^{* * *}$ & $-3.863^{*}$ & & \\
\hline & & & $(1.363)$ & $(1.983)$ & & & & & $(1.485)$ & $(2.213)$ & & \\
\hline \multirow[t]{2}{*}{ Conflict region*Receives remittances } & & & & 2.821 & & & & & & -4.582 & & \\
\hline & & & & $(2.674)$ & & & & & & $(2.978)$ & & \\
\hline \multirow[t]{2}{*}{$\mathrm{N}$ of private remitters abroad } & & & & & $-11.158^{* * *}$ & $-10.275^{* * *}$ & & & & & $-4.308^{* * *}$ & -3.631 \\
\hline & & & & & $(1.641)$ & $(2.317)$ & & & & & $(1.621)$ & $(2.461)$ \\
\hline \multirow[t]{2}{*}{$\mathrm{N}$ of private remitters in Tajikistan } & & & & & $-4.975^{* * *}$ & $-7.189^{* * *}$ & & & & & $-4.726^{* * *}$ & -1.042 \\
\hline & & & & & $(1.400)$ & $(1.981)$ & & & & & $(1.554)$ & $(2.437)$ \\
\hline \multirow[t]{2}{*}{ Conflict region*N remitters abroad } & & & & & & -1.696 & & & & & & -1.161 \\
\hline & & & & & & $(3.204)$ & & & & & & $(3.265)$ \\
\hline \multirow[t]{2}{*}{ Conflict region*N remitters in Tajikistan } & & & & & & 3.958 & & & & & & $-6.140^{*}$ \\
\hline & & & & & & $(2.707)$ & & & & & & $(3.223)$ \\
\hline $\mathrm{N}$ & 7119 & 7119 & 7119 & 7119 & 7119 & 7119 & 7402 & 7402 & 7402 & 7402 & 7402 & 7402 \\
\hline Log likelihood & -24148 & -24148 & -24151 & -24150 & -24152 & -24151 & -20128 & -20127 & -20128 & -20127 & -20129 & -20127 \\
\hline $\mathrm{N}$ of left-censored obs & 2661 & 2661 & 2661 & 2661 & 2661 & 2661 & 3949 & 3949 & 3949 & 3949 & 3949 & 3949 \\
\hline
\end{tabular}

Tobit models. Dependent variable: hours worked in the last 14 days.

Notes: * significant at $10 \%$; ** significant at $5 \%$; ** significant at $1 \%$. All regressions control for age, age squared, education level, non-wage income, household dependency ratio, indicators for being married, female household head and rural residence, and a constant term. All regressions include district-level fixed effects. Robust standard errors in parenthesis.

Data Source: As for Table 2. 
Table 9 Instrumental variable estimation: employment, hours worked and remittances

\begin{tabular}{|c|c|c|c|c|c|c|c|c|}
\hline & \multicolumn{4}{|c|}{ Panel A: Full sample } & \multicolumn{4}{|c|}{ Panel B: Conflict region } \\
\hline & \multicolumn{2}{|l|}{ IV-2SLS } & \multicolumn{2}{|l|}{ IV-Tobit } & \multicolumn{2}{|l|}{ IV-2SLS } & \multicolumn{2}{|l|}{ IV-Tobit } \\
\hline & \multicolumn{2}{|c|}{ Employed last 40 days } & \multicolumn{2}{|c|}{ Hours worked last $14 \mathrm{~d}$} & \multicolumn{2}{|c|}{ Employed last 40 days } & \multicolumn{2}{|c|}{ Hours worked last 14d } \\
\hline & men & women & men & women & men & women & men & women \\
\hline & (1) & (2) & (3) & (4) & (5) & (6) & (7) & (8) \\
\hline \multirow[t]{2}{*}{ Ln (total remittances) } & $-0.071^{* * *}$ & -0.017 & $-11.509^{* * *}$ & $-3.821^{* * *}$ & $-0.068^{* * *}$ & -0.016 & $-7.562^{* * *}$ & -0.517 \\
\hline & $(0.026)$ & $(0.019)$ & $(1.590)$ & $(1.328)$ & $(0.025)$ & $(0.031)$ & $(1.972)$ & $(1.804)$ \\
\hline $\mathrm{N}$ & 6552 & 7351 & 7119 & 7402 & 3624 & 4238 & 3982 & 4255 \\
\hline $\mathrm{R}$ squared & 0.17 & 0.12 & & & 0.19 & 0.12 & & \\
\hline Log likelihood & & & -39903.35 & -36687.28 & & & -21875.84 & -20931.03 \\
\hline $\mathrm{N}$ of left-censored obs & & & 2661 & 3949 & & & 1549 & 2305 \\
\hline Robust $F(1,62)$ (In(remittances) is endogeneous)-first stage & 6.60 & 0.22 & & & 4.52 & 0.22 & & \\
\hline p-value & 0.01 & 0.64 & & & 0.04 & 0.64 & & \\
\hline \multicolumn{9}{|c|}{ First-stage summary stats endogenenous regressor: In (remittances) } \\
\hline R-squared & 0.09 & 0.09 & & & 0.09 & 0.09 & & \\
\hline Adj. R-squared & 0.08 & 0.08 & & & 0.08 & 0.08 & & \\
\hline Partial R-squared & 0.02 & 0.03 & & & 0.02 & 0.03 & & \\
\hline Robust F $(1,62)$ (Natwork=0) & 23.92 & 30.10 & & & 11.20 & 15.07 & & \\
\hline p-value & 0.00 & 0.00 & & & 0.00 & 0.00 & & \\
\hline Weak instrument test & $2 S L S$ & $2 S L S$ & & & $2 S L S$ & $2 S L S$ & & \\
\hline Min.eigenvalue statistic=F-stat."network=0" & 161.64 & 235.94 & & & 75.36 & 116.17 & & \\
\hline 2SLS Size of nominal 5\% Wald test & 16.38 & 16.38 & & & 16.38 & 16.38 & & \\
\hline \multicolumn{9}{|l|}{ IV-Tobit } \\
\hline Wald test of exogeneity & & & 37.18 & 4.39 & & & 8.90 & 0.22 \\
\hline p-value & & & 0.00 & 0.04 & & & 0.00 & 0.64 \\
\hline
\end{tabular}

Notes: * significant at $10 \%$; ** significant at $5 \%$; *** significant at $1 \%$. All regressions controls for age, age squared, education level, non-wage income, household dependency ratio, indicators for being married, female household head and rural residence, residence in 'conflict region' and a constant term. All regressions include district-level fixed effects. Robust standard errors in parenthesis. Source: As for Table 2. 
and in Tajikistan +1 ). We instrument ln (remittances) by using a community (primary sampling unit) level size of the migration network as defined in section 3 . This variable is highly correlated with remittances as shown by the F-statistics from the first stage OLS regressions. The F-test and Wald tests for endogeneity of $\ln$ (remittances) suggest that this variable is endogenous for the labor supply of men, but exogenous with respect to employment of women (F value $=0.22$ ). In the IV-Tobit estimations for women in Column 4, we can see that $\ln$ (remittances) is endogenous with respect to hours worked (Panel A, Column 4), but exogenous for women from the 'conflict region' (Panel B, Column 8).

The estimated coefficient on the ln (remittances) in the IV models is 4.7 times higher (Table 9, Column 1) compared to its OLS estimate in Table 7 (Column 1) for men (significant at the 1 percent level). While an IV estimate of the coefficient on ln (remittances) in the IV-2SLS regressions for women is slightly higher (Column 2) that its OLS estimate, it is not statistically significant at a conventional level. In the IV-Tobit estimations, the estimated coefficients on the instrumented value of $\ln$ (remittances) are also negative and are substantially higher than their estimates in Table 8 (Columns 1 and 7).

Table 9 includes summary statistics from the first-stage regressions that are useful for identifying weak instruments. The R-squared and the adjusted R-squared are only 0.09 and 0.08 in the IV regressions for men and women. This result suggests a loss of precision associated with the IV estimation, which is expected. The partial R-squared is only 0.02 in the regressions for men and 0.03 in the regressions for women. The F-statistic values are 23.92 and 30.10 for the full sample (Panel A) of men and women and 11.2 and 15.07 for the 'conflict region' sub-sample (Panel B) which is greater than the ruleof-thumb value of 10. The test of Stock and Yogo (2005: p. 84) gives us a Wald test value of 16.38 based on 2SLS estimator. We reject the hypothesis of weak instrument presence at the 5 percent significance level Cameron and Trivedi (2009: pp. 192-193).

As the sign of the estimated coefficient on the variable of interest is consistent between the IV-2SLS and the OLS, and the IV-Tobit and Tobit models, and the measure of remittances is not endogenous to the female labor supply, we assume that our OLS and Tobit model coefficient estimates on this variable are accurate with respect to the sign of the relationship. While the OLS models here provide us with lower coefficient estimates than instrumental variable models, we are comfortable with trading the precision of the IVestimates for efficiency of the OLS and continue our analysis and discussion using the OLS framework.

\section{Effect of migration vs. remittances}

One potential explanation for the lower effect of remittances on female labor supply in Tajikistan may have to do with the fact that remittances in households where women work may not be sufficient to compensate for a loss of wages if women were to stay home ${ }^{21}$. It is also possible that the negative effect of migration on household income and the necessity to substitute for the labor of migrated household members in the household production is greater than the income effect of remittances. Since migration of household members and remittances can have opposing effects on household labor supply, we attempt to separate these two events following a strategy used by AmuedoDorantes and Pozo (2010). Some of the households in Tajikistan receive remittances but do not have household members who migrated abroad for work in the past five 
years. We take advantage of this diversity and separate the sample into households that have former migrants and households that do not have such migrants ${ }^{22}$. In effect, we separate the migration effect from the effect of remittances by focusing our attention on the labor supply of household members residing in non-migrant households (Table 10). The OLS estimate of the coefficient on ln (remittances) in the regressions with dependent variable being employed in the last 14 days in the sub-sample for men is only $1 / 3$ of the OLS estimate for the full sample (0.005 vs. 0.015$)$ and it is not statistically significant. The estimated coefficients on the dummy for the receipt of remittances or number of remitters abroad are not statistically significant either alone or when interacted with 'conflict region' dummy variable. Only the presence of remitters located in Tajikistan is statistically significantly negatively associated with a decreased supply of labor by men. Thus, it appears that the negative effect of remittances and migration on the labor force participation of men is primarily felt through the channel of migration than remittances. Since, it is men who are mostly migrants, the negative effect of migration that we observe in the data may be simply related to them waiting for their next spell of migration to start. In Table 10, the effect of remittances on the labor supply by women is statistically significantly different from zero only for women in 'conflict region' (Columns 8 and 10) and the estimated coefficients of interest are slightly higher than their estimates in Table 7.

\section{Discussion and conclusion}

The aim of this paper is to estimate the impact of remittances on the labor supply of working age men and women in post-conflict Tajikistan. Similarly to previous literature, we find that the amount of remittances received by a household has an overall negative impact on the labor force participation and labor hours supplied by men and women aged 16-65. Our results also show that the effect of remittances is stronger for men than for women. However, when we interact remittance measures with the 'conflict region' indicator, we observe that female labor supply is negatively associated with the receipt of remittances only in 'conflict regions'. The stronger effect of remittances on the labor market participation by women in 'conflict regions' is consistent with remittances being used as a coping strategy, where women from remittance receiving households may exit less desirable jobs in informal sector as found by other studies (Amuedo-Dorantes and Pozo 2006). Conditional on employment, remittances are negatively associated with the number of hours worked. Results using extensive and intensive measures of labor market participation indicate that remittances in 'conflict region' primarily affect female entry into employment. Once women are employed, the receipt of remittances does not have an impact on their hours of work. Only access to remitters in Tajikistan reduces hours of work by women suggesting their preference for economic security.

In the households that do not have migrants but have reported receiving remittances, remittances have no statistically significant effect on the labor supply by men, suggesting that the primary channel of reduction in labor supply is labor migration at the household level. In Tajikistan, most of the labor migrants are male (Olimova and Bosc 2003). Thus men may reduce their labor supply in the local market as they expect to migrate in the near future since the differences in wages across countries are substantial ${ }^{23}$. The regression results where we include a dummy variable for an individual being a former labor migrant support this interpretation ${ }^{24}$. 
Table 10 Sample of households that do not have return migrants: labor force participation, remittances and conflict

\begin{tabular}{|c|c|c|c|c|c|c|c|c|c|c|c|c|}
\hline & \multicolumn{6}{|c|}{ Panel A: Men } & \multicolumn{6}{|c|}{ Panel B: Women } \\
\hline & (1) & $(2)$ & (3) & (4) & (5) & (6) & (7) & (8) & (9) & (10) & (11) & (12) \\
\hline \multirow[t]{2}{*}{ Ln(total remittances from abroad and Tajikistan) } & -0.005 & -0.001 & & & & & -0.005 & 0.003 & & & & \\
\hline & $(0.004)$ & $(0.006)$ & & & & & $(0.004)$ & $(0.004)$ & & & & \\
\hline \multirow[t]{2}{*}{ Conflict region*Ln(total remittances) } & & -0.007 & & & & & & $-0.014^{* *}$ & & & & \\
\hline & & $(0.008)$ & & & & & & $(0.006)$ & & & & \\
\hline \multirow[t]{2}{*}{ Receives remittances (dummy) } & & & -0.028 & -0.008 & & & & & -0.025 & 0.016 & & \\
\hline & & & $(0.022)$ & $(0.033)$ & & & & & $(0.023)$ & $(0.024)$ & & \\
\hline \multirow[t]{2}{*}{ Conflict region*Receives remittances } & & & & -0.038 & & & & & & $-0.076^{* *}$ & & \\
\hline & & & & $(0.043)$ & & & & & & $(0.038)$ & & \\
\hline \multirow{2}{*}{$\mathrm{N}$ of private remitters abroad } & & & & & 0.007 & 0.04 & & & & & 0.012 & 0.017 \\
\hline & & & & & $(0.034)$ & $(0.042)$ & & & & & $(0.034)$ & $(0.020)$ \\
\hline \multirow[t]{2}{*}{$\mathrm{N}$ of private remitters in tajikistan } & & & & & $-0.037^{* *}$ & -0.039 & & & & & $-0.032^{* *}$ & -0.003 \\
\hline & & & & & $(0.014)$ & $(0.025)$ & & & & & $(0.014)$ & $(0.027)$ \\
\hline \multirow[t]{2}{*}{ Conflict region* $\mathrm{N}$ remitters abroad } & & & & & & -0.074 & & & & & & -0.012 \\
\hline & & & & & & $(0.063)$ & & & & & & $(0.075)$ \\
\hline \multirow[t]{2}{*}{ Conflict region*N remitters in Tajikistan } & & & & & & 0.004 & & & & & & -0.041 \\
\hline & & & & & & $(0.030)$ & & & & & & $(0.031)$ \\
\hline $\mathrm{N}$ & 5220 & 5220 & 5220 & 5220 & 5220 & 5220 & 5696 & 5696 & 5696 & 5696 & 5696 & 5696 \\
\hline R squared & 0.24 & 0.24 & 0.24 & 0.24 & 0.24 & 0.24 & 0.11 & 0.11 & 0.11 & 0.11 & 0.11 & 0.11 \\
\hline
\end{tabular}

Notes: * significant at $10 \% ; * *$ significant at $5 \%$; *** significant at $1 \%$. All regressions controls for age, age squared, education level, non-wage income, household dependency ratio, indicators for being married, female household head and rural residence, and a constant term. All regressions include district-level fixed effects. Robust standard errors in parenthesis.

Data Source: As for Table 2. 
The lower effect of remittances on the labor supply of women compared to men may be also explained by the fact that if households that have been receiving remittances or had migrant household members for a long time, such households may have adjusted their consumption instead of their labor supply. The difference in consumption expenditures between households that receive remittances and those that do not is very small. There could also be an issue with respect to who controls the distribution of remittances. If women do not have access to remittances in a household Tajikistan as suggested by a recent ODIHR- OSCE (2012) report ${ }^{25}$, then we should not observe significant changes in the labor supply of women in response to remittances. Unfortunately available data do not allow us to test this hypothesis further.

A final set of possible explanations is related to individual attitudes and preferences towards risk: the lower response of women's labor supply to remittances may have to do with women being more risk averse. There is a large literature that studies economic decision making and risk attitudes of men and women, suggesting that women are more risk averse than men (see review by Croson and Gneezy 2009). At the moment there are no data available to test this hypothesis explicitly in the case of Tajikistan as this would require an experimental research design. This area of research should be explored for further work on individual behavior in conflict settings. For instance, Voors et al. (2012) report significant changes in tastes, preferences and risk aversion in conflict situations.

The results presented in the paper offer several important contributions to the literature on the effects of remittances on households in developing economies. Firstly, the results show strong evidence for the differential way in which men and women respond to remittances with respect to their labor supply decisions. This observation provides a further evidence for the importance of research on intra-household decision-making processes, as well as on the differences in labor supply decisions by gender. Secondly, the study illustrates that migration of household members is the primary factor explaining reduced labor supply by men in household that receive remittances. Further, entry into employment by women is only responsive to remittances in 'conflict regions' but not in other parts of Tajikistan. Analyses using only remittances or only conflict data may provide an incomplete picture of labor supply decisions between and within households. Our results motivate further research on how households respond to multiple events.

\section{Endnotes}

1 Tajikistan receives $0.4-1$ billion US dollars in remittances every year which amounts to 20 - 50 percent of total GDP (Kireyev 2006). In comparison, remittances in Bangladesh, Egypt and Morocco - traditionally some of the highest remittancereceiving countries in the world - represent around 10 percent of total GDP. In the dataset, remittances from family members and other relatives in Tajikistan constitute about 23 percent of total household expenditure for those households that report receiving remittances (authors' calculations using TLSS 2003 data). Remittances are the second largest source of income for households after wages (World Bank 2003). Table 11 in Appendix provides details on the size of remittances in relation to various items in the balance of payments of Tajikistan.

2 Definition of "currently employed status" is based the 2003 TLSS, Module 5, part A, questions 1-3, 5 and 6 . This definition is consistent with the ILO definition of 
employment (http://stats.oecd.org/glossary/detail.asp?ID=764. Accessed: September 25, 2012) that includes individuals above certain age who were employed (worked for at least one hour) during a specified short period of time of either one week or one day. The employment categories include paid and self-employment.

${ }^{3}$ We also estimated regressions with "workforce participation" as a dependent variable and the results were very similar to those reported for "employed in the last 14 days".

${ }^{4}$ The calculation of non-wage income is based on Lokshin and Glinskaya (2009: page 493, ft 9). The non-wage income includes pensions for old-age, disability, survivors' pension, special merit, social pensions, pensions based on years of experience, compensation to victims of Chernobyl, Afghan veterans and any other allowances not mentioned (2003 TLSS: Module 7, part C).

${ }^{5}$ Yang and Choi (2007) show that remittances are positively related to negative shocks and thus are countercyclical.

${ }^{6}$ Azzari and Zezza (2011) also used other community level measures of migration, such as share of males to females ages 20-39 in 2003 and the number of households in a community who speak Russian as a second language. These two variables are likely to be also correlated with the demand for and supply of labor, and therefore we do not use them as instruments.

${ }^{7}$ In the 2003 TLSS survey instrument, such individuals and institutions are defined as "donors".

${ }^{8}$ According to Bliss (2010: 276), the Tajik government imposed a blockade on food supplies to GBAO as Pamiri who populate the region initially were allied with the Gharmi opposition forces. Bliss notes that few Pamiri actually fought against the government forces but by association were targeted which led to murder of many Pamiri in Khatlon and Dushanbe and the flight of Pamiri to GBAO protected by the mountains. His account is also supported by HRW $(1993,1995)$ reports of targeted killings and disappearances of Pamiri men in Khatlon region and in Dushanbe.

${ }^{9}$ The conflict events are defined as reports of destruction of communities and infrastructure, fighting between the government forces and the opposition, violence against civilians, forced displacement, killings, assassinations, kidnappings, and targeted murders committed by the opposition or government supporters. For more details about the conflict see Shemyakina (2012), Appendix A.

10 Vechernii Dushanbe (Evening Dushanbe) and Narodnaya Gazeta (People's Newspaper).

11 The excluded districts in Kulob zone are Baljuvon, Khovaling, Muminobod and Temurmalik (former Sovetskii). Only the last two districts were surveyed in the 2003 TLSS.

${ }^{12}$ The Tajik Living Standards Survey (TLSS) data are available at http://go.worldbank. org/X0OZBE6PJ0.

${ }^{13}$ The 2003 data do not contain socio-demographic information on migrants who were abroad at the time of the survey and who sent remittances and thus we are not able to control for these in our analysis. The only information available on individual migrants is their relationship to the household head. Most migrants fall into one of three categories: the household head himself or herself, and spouses and children of household heads.

${ }^{14}$ The cut-off points are based on the census data which are presented by age sub-groups.

${ }^{15}$ Kulob group of districts includes Kulob (also Kulyab), Kulob-city, Vose, Temurmalik (former Sovetskii), Farkhor, Hamadoni (former Moskovskii), Shurobod (also Shuroobod), 
Muminobod, Khovaling, Baljuvon and Danghara districts. The remaining districts in Khatlon belong to Kurgan-Tube zone (also called Kurgan-Tube group of districts).

${ }^{16}$ We also used workforce participation instead of employment and the results are very similar.

17 The estimated coefficients on the control variables have similar signs to those reported in the literature. Married men/women are more/less likely to be in the workforce. Labor force participation increases with age, and is higher for more educated people and those who live in rural areas. Rural men and women are more likely to participate in the labor force. Women and men from larger households are less likely to be employed. The estimated coefficients on the dependency ratio and the indicator for female household head are not statistically significant. Non-labor income has a negative and statistically significant impact on male labor force participation and has no statistically significant impact on female labor supply.

${ }^{18}$ We use an actual number of remitters instead of dummy variables for having a remitter because the actual number allows us to exploit a variation in the number of remitters in the analysis.

${ }^{19}$ As all of our regressions include district-level fixed effects, we cannot include 'conflict region' as a level variable because it is a district-level measure.

${ }^{20}$ For the set of control variables, the sign and significance levels of the estimated regression coefficients on the set of control variables in Table 8 are similar to the estimates in Table 7. The number of labor hours supplied increases with age, education and residence in the rural area and decreases for these coming from large households. Married men/women work longer/shorter hours respectively. The effect is larger for women. Nonwage income has negative and statistically significant effect on the hours worked by men but not by women. The estimated coefficients on the dependency ratio and a dummy for female household head are not statistically significant in any of the regressions.

${ }^{21}$ Wives of Tajik migrants surveyed by the IOM (2009) noted that the remittances received were not sufficient to pay for basic expenditures, some of them received no remittances at all, and that the frequency of remittances varied. Since remittances were not sufficient, many women had to find other ways to provide for themselves and move in with their extended families or in-laws (IOM 2009).

${ }^{22}$ Unfortunately, the 2003 TLSS survey does not allow us to distinguish migrants who were abroad at the time of the survey.

${ }^{23}$ Between 1998 and 2003, an average monthly wage in Tajikistan was between 7 and 21 USD, and an average wage in Russia was between 66 and 306 U.S. dollars (IMF 2001, 2005).

${ }^{24}$ A third (164 out of 483, or 34 percent) of former male migrants indicated they were neither working or had looked for a job in the past 30 days. 25.0 percent indicated that they are "housewives", 20.1 percent - that there were no jobs, 20.1 percent - "other reason", 12.2 percent said that they do not want to work and 6.7 percent said that they were in school. Among the 49 former female migrants, 22 did not work or look for work at the time of the survey. Among them 81 percent were housewives, and the rest indicated that they were either in school or did not want to work with the number equally split between these two.

${ }^{25}$ In Tajikistan wives of migrants typically live with their in-laws and are not considered to be heads of their households when the husband is absent. The in-laws typically assume this duty and take over control over remittances sent by their sons (ODIHR OSCE 2012: p 6). 


\section{Appendix}

Table 11 provides details on the size of remittances in relation to various items in the balance of payments of Tajikistan.

Table 11 Migrant remittances and their relative size in Tajikistan balance of payments

\begin{tabular}{lllllll}
\hline & $\mathbf{2 0 0 0}$ & $\mathbf{2 0 0 1}$ & $\mathbf{2 0 0 2}$ & $\mathbf{2 0 0 3}$ & $\mathbf{2 0 0 4}$ & $\mathbf{2 0 0 5}$ \\
\hline Net Migrant Remittances & 0 & -1 & 65 & 82 & 133 & 321 \\
Inflows & 1 & 4 & 78 & 146 & 252 & 465 \\
Outflows & -1 & -5 & -13 & -64 & -119 & -144 \\
Gross remittances/ Exports, (percent) & 0 & 1 & 11 & 18 & 23 & 42 \\
Gross remittances/ Trade Deficit, (percent) & 3 & 3 & 63 & 72 & 167 & 146 \\
Gross remittances/ FDI, (percent) & 3 & 47 & 356 & 456 & 93 & 852 \\
Gross remittances/ Net Borrowing, (percent) & 2 & 70 & 560 & 456 & -149 & 932 \\
Gross remittances/ Gross Reserves,(percent) & 1 & 4 & 82 & 108 & 133 & 207 \\
\hline
\end{tabular}

Data source: the IMF and the National Bank of Tajikistan (as quoted in World Bank, 2006).

The summary statistics for the analytical sample are shown in Table 12 below.

Table 12 Individual summary statistics

\begin{tabular}{lllll}
\hline Variable & $\begin{array}{l}\text { Full } \\
\text { sample }\end{array}$ & $\begin{array}{l}\text { Non conflict } \\
\text { region }\end{array}$ & $\begin{array}{l}\text { Conflict } \\
\text { region }\end{array}$ & $\begin{array}{l}\text { Difference in means (2)- } \\
\text { (3) }\end{array}$ \\
\hline Age, years & $(1)$ & $(2)$ & $(3)$ & $(4)$ \\
Female & 32.63 & 32.92 & 32.45 & $0.47^{* *}$ \\
Married (indicator) & 0.51 & 0.50 & 0.51 & $-0.02^{*}$ \\
Education & 0.63 & 0.66 & 0.61 & $0.05^{*}$ \\
N hours worked & 10.13 & 10.48 & 9.92 & $0.56^{* * *}$ \\
N obs & 25.76 & 28.32 & 24.17 & $4.15^{* * *}$ \\
Worked last 14 days & 14521 & 6284 & 8237 & \\
(indicator) & 0.58 & 0.57 & 0.58 & $-0.01^{* * *}$ \\
In the workforce (indicator) & 0.60 & 0.60 & & $0.01^{* * *}$ \\
N obs & 13903 & 6041 & 7862 & \\
\hline
\end{tabular}

Notes: * significant at $10 \%$; ${ }^{* *}$ significant at $5 \%$; ${ }^{* *}$ significant at $1 \%$.

Data source: Authors' calculations using TLSS (2003.)

\section{Competing interests}

The IZA Journal of Labor \& Development is committed to the IZA Guiding Principles of Research Integrity. The authors declare that they have observed these principles.

\footnotetext{
Acknowledgement

${ }^{ \pm}$For comments and suggestions we would like to thank the managing editor of the journal, Dr. Jackline Wahba, Catalina Amuedo-Dorantes, Anke C. Plagnol, Susan Pozo, Christine Ries, John Strauss, Eik Swee, Duncan Thomas and participants at the 2007 Households in Conflict and Yale University workshop, the 2009 Annual Meeting of the Population Association of America, the 2010 AEA annual meeting, the 2010 Pacific Conference for Development Economics, the 2010 International Research Workshop of the Institute of Social Sciences (ICS, Lisbon) and the Households in Conflict Network (HiCN). Olga Shemyakina would like to thank for financial support the Georgia Institute of Technology. Shemyakina is also grateful to the University of Southern California (USC), the USC Urban Initiative and the Institute for Social Research/William Davidson Institute at the University of Michigan which supported some of the data collection when Shemyakina was a graduate student at the University of Southern California. Patricia Justino is grateful to the European Commission for funding as part of the MICROCON Integrated Project (www.microconflict.eu). The views expressed in this paper are those of the authors alone and do not necessarily reflect those of funding agencies. All mistakes are ours. Reponsible editor: Jackline Wahba.
} 


\author{
Author details \\ ${ }^{1}$ Institute of Development Studies, Sussex, UK. ${ }^{2}$ School of Economics, Georgia Institute of Technology, Atlanta, GA \\ 30332-0615, USA.
}

Received: 25 May 2012 Accepted: 11 November 2012

Published: 31 December 2012

\title{
References
}

Acosta P (2006) "Labor Supply, School Attendance, and Remittances from International Migration: The Case of El Salvador," World Bank Policy Research Working Paper 3903. World Bank

Adams RH (2005) "Remittances, Household Expenditure and Investment in Guatemala". In: Policy Research Working Paper N 3532. The World Bank, Washington, D.C

Amuedo-Dorantes C, Pozo S (2006) Migration, Remittances, and Male and Female Employment Patterns. American Economic Review 96(2):222-226

Amuedo-Dorantes C, Pozo S (2010) Accounting for Remittances and Migration Effects on Children's Schooling. World Development 38(12):1747-1759

Anderson MB (1999) Do No Harm: How Aid Can Support Peace - or War. Lynne Rienner Publishers,

Annan J, Blattman C, Mazurana D, Carlson K (2011) Civil War, Reintegration, and Gender in Northern Uganda. Journal of Conflict Resolution 55(6):877-908

Azzari C, Zezza A (2011) International migration and nutritional outcomes in Tajikistan. Food Policy 36(1):54-70

Beaman L (2012) Social Networks and the Dynamics of Labor Market Outcomes: Evidence from Refugees Resettled in the U.S. Review of Economic Studies 79(1):128-161

Binzel C, Assaad R (2011) "Egyptian Men Working Abroad: Labor-Supply Responses by the Women Left Behind.". Labour Economics 18(Supplement 1):98-114

Blattman C, Miguel E (2010) Civil War. Journal of Economic Literature 48(1):3-57

Bliss F (2010) Social and Economic Change in the Pamirs (Gorno-Badakhshan, Tajikistan). Routledge: Taylor and Francis Group, 2010, London and New York

Bozzoli C, Muller C (2010) "The Impact of Violence on Income Expectations", unpublished manuscript. DIW Berlin

Brück T, Schindler K (2009) The Impact of Violent Conflicts on Households: What We Know and What Should We Know about War Widows? Oxford Development Studies 37(3):289-309

Cameron AC, Trivedi PK (2005) Microeconometrics: Methods and Applications. Cambridge University Press

Cameron AC, Trivedi PK (2009) Microeconometrics Using Stata. Stata Press

Capisani GR (2000) The Handbook of Central Asia: a comprehensive survey of the new republics. I. B. Tauris, London; New York

Chang H, Dong X-Y, MacPhail (2011) "Labor Migration and Time Use Patterns of the Left-behind Children and Elderly in Rural China." World Development 39(12):2199-2210

Committee SS (2006) Tajikistan: 15 years of the State's Independence. State Statistical Committee of Republic of Tajikistan, Dushanbe

Croson R, Gneezy U (2009) Gender Differences in Preferences. Journal of Economic Literature 47(2):448-474

Czaika M, Kis-Katos K (2009) "Civil Conflict and Displacement: Village-Level Determinants of Forced Migration in Aceh". Journal of Peace Research 46(3). May

Damon AL (2007) "Household Labor Allocation in Remittance-Receiving Households: The Case of El Salvador". Department of Economics, University of Minnesota

Damon AL (2010) Agricultural Land Use and Asset Accumulation in Migrant Households: The Case of El Salvador. Journal of Development Studies 46(1):162-189

Engel S, Ibáñez AM (2007) Displacement Due to Violence in Colombia: A Household-Level Analysis. Economic Development and Cultural Change 55:335-365

Fernández M, Ibáñez A-M, Peña X (2011) "Adjusting the Labor Supply to Mitigate Violent Shocks: Evidence from Rural Colombia," Policy Research Working Paper. World Bank, Washington, DC

Funkhouser E (1992) Migration from Nicaragua: Some Recent Evidence. World Development 20(8):1209-1218

Goldring L (2002) Rethinking Remittances: Social and Political Dimensions of Individual and Collective Remittances, CERLAC Working Paper Series. University of York

Gomart E (2003) Between Civil War and Land Reform: Among the Poorest of the Poor in Tajikistan. In: Dudwick N, Gomart E, Marc A (ed) When things fall apart: qualitative studies of poverty in the former Soviet Union. World Bank Washington, D.C.

Hanson GH (2007) Emigration, Remittances, and Labor Force Participation in Mexico. Integration and Trade Journal 27:73-103 Human Rights Watch (HRW) (1993) "Human Rights in Tajikistan: In the Wake of Civil War". Human Rights Watch, New York Human Rights Watch (HRW) (1995) "Return to Tajikistan: Continued Regional and Ethnic Tensions". Human Rights Watch, Helsinki, Finland. May 1995, Vol. 7, No 9

International Monetary Fund (IMF) (2001) "IMF Country Report No. 01/69. Republic of Tajikistan: Statistical Appendix" International Monetary Fund. (IMF) (2005) "IMF Country Report No. 05/131. Republic of Tajikistan: Selected Issues and Statistical Appendix". April

International Monetary Fund. (IMF) (2006) Republic of Tajikistan: Recent Economic Developments and Statistical Appendix. International Monetary Fund, Washington, D.C.

International Organization for Migration (IOM) (2009) Abandoned Wives of tajik Labor Migrants. IOM Dushanbe, Tajikistan. August 2009. Accessed: October 3, 2012. http://www.iom.tj/pubs/abandoned_wives_English.pdf

Justino P (2009) Poverty and Violent Conflict: A Micro-Level Perspective on the Causes and Duration of Warfare. Journal of Peace Research 46(3)

Justino P (2012) "War and Poverty". In: Michelle G, Stergios S (ed) Handbook of the Economics of Peace and Security. Oxford University Press

Killingsworth MR (1983) Labour Supply. Cambridge University Press, Cambridge 
Kireyev A (2006) The Macroeconomics of Remittances: The Case of Tajikistan. IMF Working Paper. Policy Development and Review Department. International Monetary Fund, Washington, D.C

McKenzie D, Rapoport H (2007) Network Effects and the Dynamics of Migration and Inequality: Theory and Evidence from Mexico. Journal of Development Economics 84(1):1-24

Menon N, Rodgers Y (2011) War and Women's Work: Evidence from the Conflict in Nepal. In: World Bank Policy Research Working Paper WPS5745

Munshi K (2003) Networks in the Modern Economy: Mexican Migrants in the U.S. Labor Market. Quarterly Journal of Economics. 118(2):549-597

Nazriev D, Sattorov I (2005) Respublika Tadzhikistan: Istorya Nezavisimosti. God 1992. [Republic of Tajikistan: History of Independence. Year 1992]. Erfon, Dushanbe

Nazriev D, Sattorov I (2006) Respublika Tadzhikistan: Istorya Nezavisimosti. God 1993. [Republic of Tajikistan: History of Independence. Year 1993]. Erfon, Dushanbe

Office for Democratic Institutions and Human Rights (ODIHR- OSCE) (2012) "Social and Economic Inclusion of Women from Migrant Households in Tajikistan". Organization for Security and Co-operation in Europe, 2012, Dushanbe. Accessed Oct. 3rd, http://www.osce.org/odihr/93637

Rodriguez ER, Tiongson ER (2001) Temporary Migration Overseas and Household Labor Supply: Evidence from Urban Philippines. International Migration Review 35(3):709-725

Shemyakina O (2012) "Patterns in Female Age at First Marriage and Tajik Armed Conflict," Mimeo. Georgia Institute of Technology, Atlanta

State Statistical Committee (2002) "Vozrastnoi Sostav Naseleniya Respubliki Tajikistan: Po Dannum Vseobshei Perepisi Naseleniya 2000 Goda. [Age Structure of the Population of the Republic of Tajikistan: According to the 2000 Census Data]". In: Djabbarov OA (ed). State Statistical Committee of Republic of Tajikistan, Dushanbe

Stock JH, Yogo M (2005) Testing for Weak Instruments in Linear Iv Regression. In: Andrews DWK, Stock JH (ed) Indentification and Inference for Econometric Models: Essays in Honor of Thomas Rothenberg. Cambridge University Press, Cambridge

Tadjbakhsh S (1996) "The Women's Economic Survey of Tajikistan," Dushanbe. UNIICR and Relief International, Tajikistan Voors MJ, Nillesen EEM, Verwimp P, Bulte EH, Lensink R, Van Soest DP (2012) Does Conflict Affect Preferences? Results from Field Experiments in Burundi. American Economic Review 102(2):941-964

Winters P, de Janvry A, Sadoulet E (2001) Family and Community Networks in Mexico-U.S. Migration. Journal of Human Resources 36(1):159-184

World Bank (2006) Tajikistan Policy Note: Enhancing the Development Impact of Remittances. June. Report No. 35771TJ. Poverty Reduction and Economic Management Unit, Europe and Central Asia

Yang D, Choi HJ (2007) Are Remittances Insurance? Evidence from Rainfall Shocks in the Philippines. World Bank Economic Review 21(2):219-248

doi:10.1186/2193-9020-1-8

Cite this article as: Justino and Shemyakina: Remittances and labor supply in post-conflict Tajikistan. IZA Journal of Labor \& Development 2012 1:8.

\section{Submit your manuscript to a SpringerOpen ${ }^{\circ}$ journal and benefit from:}

- Convenient online submission

Rigorous peer review

- Immediate publication on acceptance

- Open access: articles freely available online

- High visibility within the field

- Retaining the copyright to your article

Submit your next manuscript at $\boldsymbol{\nabla}$ springeropen.com 